\title{
Site Classification for Standard Modular Hydropower Development: Characterizing Stream Reaches by Module Need
}

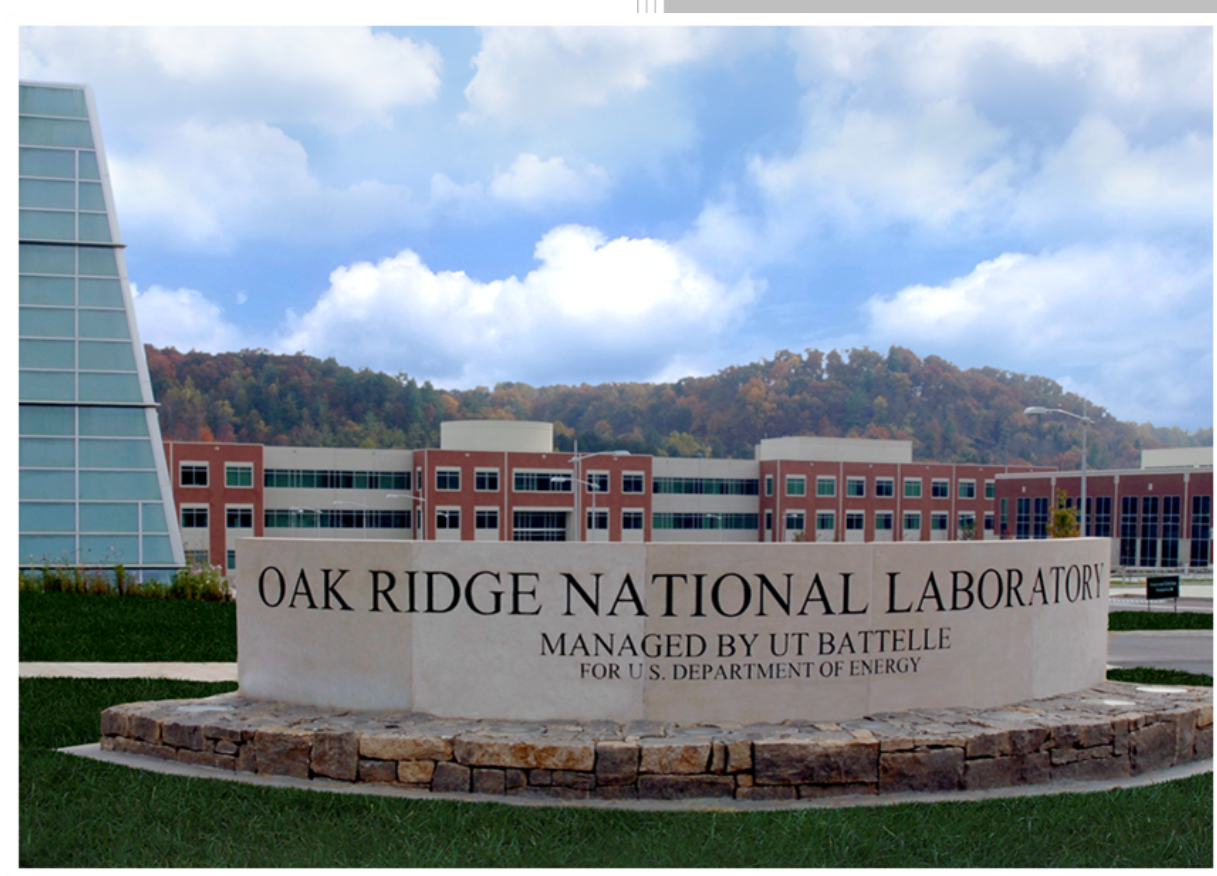

Mark Bevelhimer Chris DeRolph Adam Witt

July 2018 


\section{DOCUMENT AVAILABILITY}

Reports produced after January 1, 1996, are generally available free via US Department of Energy (DOE) SciTech Connect.

Website www.osti.gov

Reports produced before January 1, 1996, may be purchased by members of the public from the following source:

National Technical Information Service

5285 Port Royal Road

Springfield, VA 22161

Telephone 703-605-6000 (1-800-553-6847)

TDD 703-487-4639

Fax 703-605-6900

E-mail info@ntis.gov

Website http://classic.ntis.gov/

Reports are available to DOE employees, DOE contractors, Energy Technology Data Exchange representatives, and International Nuclear Information System representatives from the following source:

Office of Scientific and Technical Information

PO Box 62

Oak Ridge, TN 37831

Telephone 865-576-8401

Fax 865-576-5728

E-mail reports@osti.gov

Website http://www.osti.gov/contact.html

This report was prepared as an account of work sponsored by an agency of the United States Government. Neither the United States Government nor any agency thereof, nor any of their employees, makes any warranty, express or implied, or assumes any legal liability or responsibility for the accuracy, completeness, or usefulness of any information, apparatus, product, or process disclosed, or represents that its use would not infringe privately owned rights. Reference herein to any specific commercial product, process, or service by trade name, trademark, manufacturer, or otherwise, does not necessarily constitute or imply its endorsement, recommendation, or favoring by the United States Government or any agency thereof. The views and opinions of authors expressed herein do not necessarily state or reflect those of the United States Government or any agency thereof. 
Environmental Sciences Division

\title{
STANDARD MODULAR HYDROPOWER: SITE CLASSIFICATION
}

\author{
Mark Bevelhimer \\ Chris DeRolph \\ Adam Witt
}

Date Published: July 2018

\author{
Prepared by \\ OAK RIDGE NATIONAL LABORATORY \\ Oak Ridge, TN 37831-6283 \\ managed by \\ UT-BATTELLE, LLC \\ for the \\ US DEPARTMENT OF ENERGY \\ under contract DE-AC05-00OR22725
}





\section{CONTENTS}

\section{LIST OF FIGURES}

LIST OF TABLES

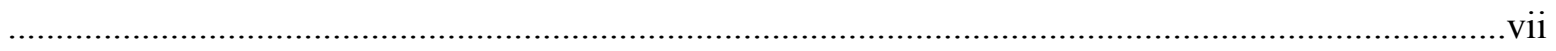

ABBREVIATIONS, ACRONYMS, AND INITIALISMS

ACKNOWLEDGMENTS

1. INTRODUCTION

2. CLASSIFICATION APPROACH

.

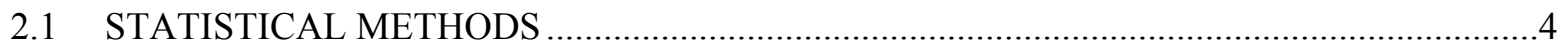

2.2 MODULE-SPECIFIC CLASSIFICATION CATEGORIES ...........................................

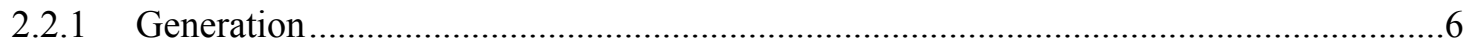

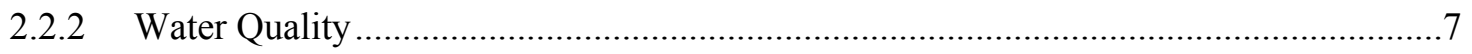

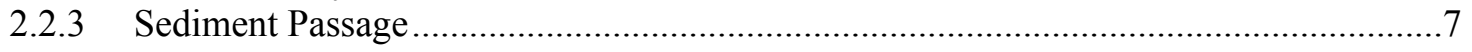

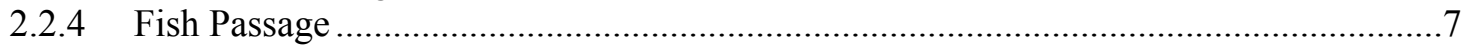

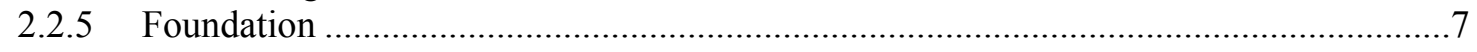

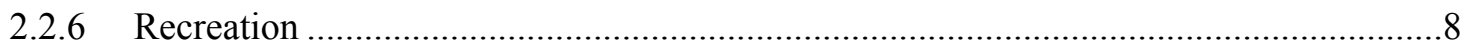

3. RESULTS

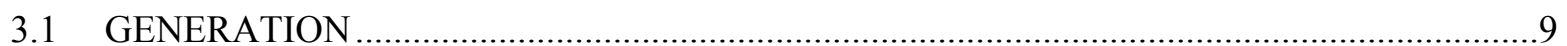

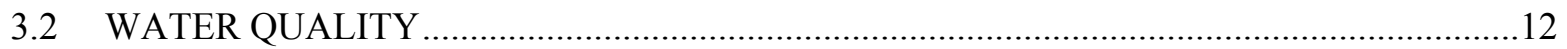

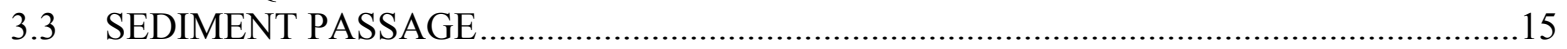

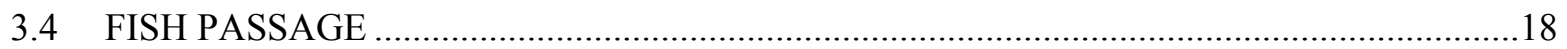

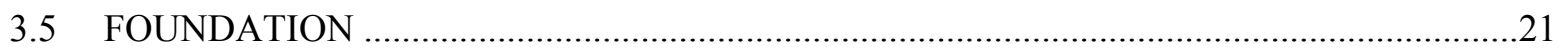

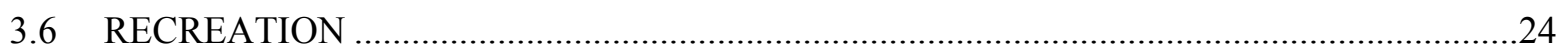

4. DISCUSSION

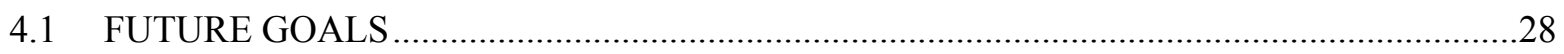

APPENDIX A. DATA VARIABLES AND SOURCES 



\section{LIST OF FIGURES}

Figure 1. Maps of the k-means clusters 1 through 5 (top panel) and 6 through 10 (bottom panel) based on characteristics related to hydropower generation.

Figure 2. Count of US NHD stream reaches (1) in each of ten K-means generation clusters (top panel), (2) associated with identified NSD sites (middle panel), and 3) associated with existing hydropower dams (bottom panel).

Figure 3. Maps of the k-means clusters 1 through 5 (top panel) and 6 through 10 (bottom panel) based on characteristics related to water quality.

Figure 4. Count of US NHD stream reaches (1) in each of ten K-means water quality clusters (top panel), (2) associated with identified NSD sites (middle panel), and (3) associated with existing hydropower dams (bottom panel).

Figure 5. Maps of the k-means clusters 1 through 5 (top panel) and 6 through 10 (bottom panel) based on characteristics related to sediment passage.

Figure 6. Count of US NHD stream reaches (1) in each of ten K-means sediment passage clusters (top panel), (2) associated with identified NSD sites (middle panel), and (3) associated with existing hydropower dams (bottom panel).

Figure 7. Maps of the k-means clusters 1 through 5 (top panel) and 6 through 10 (bottom panel) based on characteristics related to fish passage.

Figure 8. Count of US NHD stream reaches (1) in each of ten K-means fish passage clusters (top panel), (2) associated with identified NSD sites (middle panel), and (3) associated with existing hydropower dams (bottom panel).

Figure 9. Maps of the k-means clusters 1 through 5 (top panel) and 6 through 10 (bottom panel) based on characteristics related to foundational support.

Figure 10. Count of US NHD stream reaches (1) in each of ten K-means foundation clusters (top panel), (2) associated with identified NSD sites (middle panel), and (3) associated with existing hydropower dams (bottom panel).

Figure 11. Maps of the k-means clusters 1 through 5 (top panel) and 6 through 10 (bottom panel) based on characteristics related to supporting recreation uses.

Figure 12. Count of US NHD stream reaches (1) in each of ten K-means recreation clusters (top panel), (2) associated with identified NSD sites (middle panel), and (3) associated with existing hydropower dams (bottom panel). 



\section{LIST OF TABLES}

Table 1. Variables used in clustering analyses.

Table 2. Number and defining characteristics of stream reaches classified into ten different clusters as a result of K-means clustering analysis for generation potential.

Table 3. Number and defining characteristics of stream reaches classified into ten different clusters as a result of $\mathrm{K}$-means clustering analysis for water quality.

Table 4. Number and defining characteristics of stream reaches classified into ten different clusters as a result of $\mathrm{K}$-means clustering analysis for sediment passage.

Table 5. Number and defining characteristics of stream reaches classified into ten different clusters as a result of K-means clustering analysis for fish passage.

Table 6. Number and defining characteristics of stream reaches classified into ten different clusters as a result of $\mathrm{K}$-means clustering analysis for project foundation.

Table 7. Number and defining characteristics of stream reaches classified into ten different clusters as a result of $\mathrm{K}$-means clustering analysis for recreation.

Table 8. Examples of classification data to be used to inform module need and module design requirements.

Table A1. Descriptors of variables (and their sources) used in site classification clustering analysis.

Table A2. Data sources with links. 



\section{ABBREVIATIONS, ACRONYMS, AND INITIALISMS}

$\begin{array}{ll}\text { cfs } & \text { cubic feet per second } \\ \text { DB } & \text { database } \\ \text { EPA } & \text { Environmental Protection Agency } \\ \text { HUC } & \text { Hydrologic Unit Code } \\ \text { MAF } & \text { mean annual flow } \\ \text { MSU } & \text { Michigan State University } \\ \text { NERC } & \text { North American Electric Reliability Corporation } \\ \text { NHAAP } & \text { National Hydropower Asset Assessment Program } \\ \text { NHD } & \text { National Hydrographic Dataset } \\ \text { NLCD } & \text { National Land Cover Database } \\ \text { NPD } & \text { non-powered dam } \\ \text { NSD } & \text { new stream-reach development } \\ \text { NSDI } & \text { National Spatial Data Infrastructure } \\ \text { ORNL } & \text { Oak Ridge National Laboratory } \\ \text { RPS } & \text { Renewable Portfolio Standard } \\ \text { SMH } & \text { Standard modular hydropower } \\ \text { USGS } & \text { University of Tennessee-Knoxville } \\ \text { UTK } & \end{array}$





\section{ACKNOWLEDGMENTS}

The authors would like to acknowledge and express their appreciation to all the following individuals and programs for their review, comments, and support of this report and support of Standard Modular Hydropower research efforts.

\section{US Department of Energy}

- Water Power Technologies Office (project sponsor)

\section{Oak Ridge National Laboratory}

- Charlie Horak, Technical writer/editor

- Deborah Counce, Technical writer/editor

- Kevin Stewart, technical reviewer

- Missy Miller, administrative assistant

- Priscilla Henson, ORNL Publications manager

- Scott DeNeale, project manager

\section{University of Tennessee-Knoxville}

- Dr. Thanos Papanicolaou, professor and director of Hydraulics and Sedimentation Laboratory

- Dr. Benjamin Abban, post-doctoral research associate

- Sarah Pierce, MS student in water resource engineering 



\section{INTRODUCTION}

Oak Ridge National Laboratory (ORNL) is leading a research effort to redefine small hydropower development through a new research effort called "Standard Modular Hydropower" (SMH), which seeks to establish the site characteristics, design envelope specifications, and technology characteristics of nextgeneration small, low-head hydropower plants. The SMH philosophy is that a limited number of standardized passage, generation, and foundation modules can be deployed at a single site and across several sites to assemble a fully functional, environmentally compatible hydroelectric facility. The modules together must reduce the environmental impacts of development compared with conventional approaches, and the facility must deploy at a cost competitive with that of comparable renewable energy resources.

Site classification is a key standardizing concept and component of SMH research, addressing the perception that hydropower development is predominantly site-specific. Site classification consists of analyses and tools that identify similarities in stream-reach, landscape, and biological characteristics across river systems. These similarities are classified into a finite number of clusters such that differences among characteristics within a cluster are limited. In theory, stream reaches within a given cluster share enough common characteristics that, should development be pursued on any given stream reach, design requirements would not vary significantly across sites. A combination of standard generation, passage, and foundation modules could be deployed at a large group of sites within a given cluster with few to no changes in major design features.

Site classification has two main objectives: (1) to identify classes of module needs (e.g., fish passage or sediment transport) and (2) to align need classes with functional design requirements (e.g., achieving injury-free downstream passage for fish). For example, sites or river reaches that have similar stream gradient, hydrology, and migratory fish species would be expected to have similar fish passage needs and design requirements. Site classification will include information on and incorporate issues related to the presence of migratory fish species, landscape characteristics, population density, sediment characteristics, existing water quality issues, and recreational services provided by the river.

To achieve a standard site classification, it is necessary to develop tools that classify or group potential sites or development regions into similar classes so that development is less site-specific. Site classification will leverage previous and ongoing research into stream classification, mitigation prediction, and environmental metrics to maximize the efficiencies that can result from systematically applying knowledge and rubrics for how environmental and ecological systems respond to disturbances. It is impossible to eliminate all site specificity from hydropower development, but future development efforts can include judicious application of validated site classification principles to select technology modules that are most appropriate for a site class, providing greater transparency, clarity, and predictability of outcomes for stakeholders.

A specific goal of site classification is to develop a framework for classifying potential SMH sites in terms useful for informing SMH development, module need, and module design requirements using existing and new classification schemes. While the current vision for SMH has focused on applications for new stream-reach development (NSD), many of the site classifications developed to date are equally useful for other applications, such as modular development at non-powered dams (NPDs) and other hydropower co-development opportunities. This report summarizes the progress made in site classification through June 2018 and presents the future direction of the site classification task. 


\section{CLASSIFICATION APPROACH}

Site classification incorporates multivariate statistical methods to classify sites (i.e., stream reaches) into clusters - i.e., groups of sites with similar attributes - based on a simultaneous consideration of physical and biological attributes of those sites. Site classification is conducted separately for six module types:

- Hydroelectric generation (generation)

- Water quality

- Sediment passage

- Downstream fish passage/upstream fish passage (fish passage)

- Structural foundation support (foundation)

- Recreation passage

This first iteration of site classification was carried out to inform module need. We classified US stream reaches based on national-scale data sets that provide physical and biological information that a hydropower developer would generally be required to know to proceed through a pre-feasibility analysis of a site. Our goal was not to rank or prioritize sites for development, or to determine optimum designs for each cluster, but rather to use dozens of variables per stream reach to establish clusters that would likely require similar passage, generation, or foundation technologies to sustain an important river function. In the future, we will conduct a second round of classifications for many of the modules to inform the development of specific module design requirements. We will also evaluate whether an amalgamation of the individual module classifications can be used to inform SMH consideration as a whole, or whether that might need to be a separate classification altogether.

\section{Classification assessment unit}

We limit classification to stream reaches with mean annual flows of between 50 and 25,000 cubic feet per second (cfs), as defined in the SMH exemplary design report (Witt et al. 2017) ${ }^{1}$ as the range most likely to be amenable to SMH development (i.e., low-head and $<10 \mathrm{MW}$ of installed capacity). Initially, we needed to decide what to classify, e.g., watersheds, catchments, individual rivers, stream reaches, or specific sites. It was additionally necessary that the object for classification be identifiable on a national level. We considered the following four options as the object of classification:

- Hydrologic Unit Codes (HUCs), 12-digit: HUCs are watersheds of various sizes that include stream reaches of different lengths. There are $\sim 87,700$ 12-digit HUCs nationwide. Classifying by HUC would run the risk of averaging conditions that represent many stream reaches and would make it more difficult to limit the analysis to streams of certain sizes.

- National Hydrographic Dataset (NHD) stream reach: River reaches defined as part of the NHD have been used in past National Hydropower Asset Assessment Program (NHAAP) work. NHD stream segments are typically defined from confluence to confluence (stream intersections) and are thus not consistent in length or associated watershed size. Across the United States, there are 2,600,000 NHD reaches, 363,000 of which have flows $>50 \mathrm{cfs}$ and $<25,000 \mathrm{cfs}$.

- Specified reach distance: An alternative to using NHD-defined reaches is to build our own stream network of a target reach length (e.g., $20 \mathrm{~km}$ ). This however, would require significant work and not provide commensurate benefit.

\footnotetext{
${ }^{1}$ Witt et al. 2017. Exemplary Design Envelope Specification for Standard Modular Hydropower Technology. ORNL/TM-2016/298/R1.
} 
- NSD site: NSD sites generated in a previous Department of Energy-funded project at ORNL already identify 11,041 potential hydropower development sites; however, because of the objectives of that analysis, the list probably doesn't include all possible SMH sites.

After consideration of these options, we chose to use the NHD stream reaches as the object of Site Classification. NHD reaches include complete national coverage and are a common reference used for a variety of academic and industry purposes. One drawback to using the NHD reaches is that each has a unique length, which means that care needs to be taken with regard to some descriptive characteristics that might be functions of or related to reach length.

\section{Variable selection}

Before performing the statistical classification analysis for a module or issue, we addressed three questions that identified the specific data coverages needed for the classification.

\section{What are the classification objectives for a particular module?}

It is necessary to define what high-level questions need to be answered to determine whether a module is needed and what kind of functionality would be required. For example, in the case of sediment transport, the primary question is

- Is there a need or desire to maintain sediment transport at the project site?

\section{If a module proves to be needed, then what information is needed to make a decision about module need and functionality?}

In the case of the sediment transport module, the second set of questions might be

- How much sediment and what types of sediment (e.g., cobble, sand, silt) need to be passed through the site?

- When and how often does sediment need to be passed?

\section{What data sets are needed (and available) to inform the statistical clustering exercise?}

The information/data needed for classification will typically be of three types:

- Instream biotic and abiotic (e.g., hydrology, fisheries, water quality)

- Watershed (e.g., land use, land cover, soil type)

- External (e.g., meteorology, human dimensions)

The precise information needed, as identified in the previous steps, will often not be available from a single data source. And in some cases, the specific data might not be available and, therefore, other variables might need to be identified that are correlated with or informative regarding the desired information.

In the case of the sediment transport example, specific variables that could be used to characterize similar groups of stream reaches might be

- $\quad$ stream flow

- runoff

- water velocity 
- stream slope

- percentage of impervious surfaces in the watershed

- percentage of agriculture in watershed

- measure of suspended sediment concentrations

The set of variables used to inform module need will likely be different from those used to inform module design requirements, although with some overlap. Table A.1 in Appendix A provides an example of how variables might differ between module need and module design analyses.

\subsection{STATISTICAL METHODS}

We used the K-means clustering analysis from the grouping analysis tool set in ArcGIS to perform the site classification. In general, this approach creates groups by iteratively placing stream reaches in groups (hereinafter referred to as "clusters") in such a way that the overall differences among reaches (as defined by the selected set of input variables) within a cluster are minimized.

For this first round of clustering analysis, we chose to set the number of clusters at ten. We thought that this number was large enough to provide some clusters of meaningful sizes from the $300,000+$ stream reaches, yet not so large that we couldn't describe the main characteristics of each of the clusters based on output information that describes which variables are most important to differentiate each cluster from the others. Because the clustering was not constricted to produce clusters of equal numbers of reaches, some clusters may be very small (i.e., fewer than 100 reaches); these clusters are generally ignored in our summary analysis. In addition, no spatial constraints were applied to the analysis, so reaches within the same cluster might be at quite a distance from one another.

The number of input variables for the clustering analysis differed among the different modules and varied from 5 to 12 (Table 1). We chose variables for each clustering exercise that best addressed the data needs defined in our variable selection as described above and avoided variables that were highly correlated.

The results of the clustering will not in themselves identify which stream reaches are the best candidates for SMH development. But the characteristics that are most correlated with each cluster (e.g., high flow or the presence of migratory salmon), and that produce differentiation among clusters, can inform various decisions regarding project development. To provide greater interpretation of clusters relative to their favorability for SMH development, we compared the distribution of NHD stream reaches in the clusters with the distribution of potential NSD sites and existing hydropower sites as identified in Oak Ridge National Laboratory's (ORNL's) NHAAP database. Clusters with a higher relative distribution of NSD sites or existing hydropower dams than the NHD reaches in the clusters might be considered as clusters that are more favorable for development, since their potential has been previously demonstrated. 
Table 1. Variables used in clustering analyses. Lowercase $x$ 's identify those variables with $R^{2} s<0.5$, indicating those with the least influence on cluster determination.

\begin{tabular}{|c|c|c|c|c|c|c|c|}
\hline \multirow[b]{2}{*}{ Metric } & \multirow[b]{2}{*}{ Description (units) } & \multicolumn{6}{|c|}{ Module } \\
\hline & & 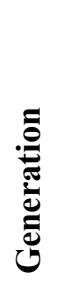 & 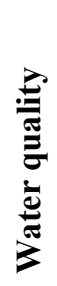 & 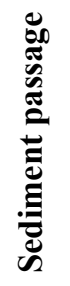 & 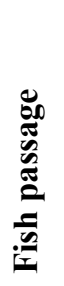 & 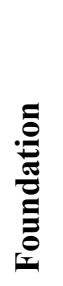 & 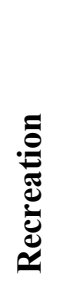 \\
\hline QA MA & Mean annual flow (MAF) (cfs) & $\mathrm{X}$ & $\mathrm{X}$ & $\mathrm{X}$ & $\mathrm{X}$ & $\mathrm{X}$ & $\mathrm{X}$ \\
\hline QA_CV & $\begin{array}{l}\text { Coefficient of variation for flow based on monthly } \\
\text { averages and annual mean }\end{array}$ & $\mathrm{x}$ & & $\mathrm{x}$ & & & \\
\hline SLOPE & Slope of stream segment & $\mathrm{X}$ & & $\mathrm{x}$ & & $\mathrm{X}$ & $\mathrm{x}$ \\
\hline VA_MA & MAF velocity $(\mathrm{m} / \mathrm{s})$ & $\mathrm{x}$ & & $\mathrm{x}$ & & $\mathrm{x}$ & \\
\hline RunoffWs & Mean runoff in watershed & $\mathrm{X}$ & & & & & \\
\hline IEOFCAT & Mean infiltration-excess overland flow in catchment & $\mathrm{X}$ & & & & & \\
\hline BFICAT & Base-flow index & $\mathrm{X}$ & & & & & \\
\hline ElevDiffWS & $\begin{array}{l}\text { Difference between maximum and minimum } \\
\text { elevation in watershed }\end{array}$ & $\mathrm{X}$ & & & & & \\
\hline PctAgWs & Percent agricultural land cover in watershed & & $\mathrm{X}$ & & & & \\
\hline PctImp2006Ws & Percent imperviousness from 2006 in watershed & & $\mathrm{X}$ & & & & \\
\hline PctImp2006Cat & Percent imperviousness from 2006 in catchment & & $\mathrm{X}$ & & & & \\
\hline PctAgCat & Percent agricultural land cover in catchment & & $\mathrm{X}$ & & & & \\
\hline FarmNCat & Sum total of nitrogen from farm areas in catchment & & $\mathrm{X}$ & & & & \\
\hline KffactWs & $\begin{array}{l}\text { The Kffactor-relative index of susceptibility of bare, } \\
\text { cultivated soil to particle detachment and transport by } \\
\text { rainfall in watershed }\end{array}$ & & $\mathrm{x}$ & & & & \\
\hline KffactCat & $\begin{array}{l}\text { The Kffactor-relative index of susceptibility of bare, } \\
\text { cultivated soil to particle detachment and transport by } \\
\text { rainfall in catchment }\end{array}$ & & $\mathrm{x}$ & & & & \\
\hline PctForWetWs & Percent forest or wetland land cover in watershed & & $\mathrm{X}$ & & & & \\
\hline PctForWetCat & Percent forest or wetland land cover in catchment & & $\mathrm{X}$ & & & & \\
\hline IEOFCat & Mean infiltration-excess overland flow in catchment & & $\mathrm{X}$ & & & & \\
\hline PopDns10Cat & Population density from 2010 census in catchment & & $\mathrm{x}$ & & & & \\
\hline RckDepCat & Mean depth to bedrock in catchment $(\mathrm{cm})$ & & & $\mathrm{X}$ & & $\mathrm{X}$ & \\
\hline PctImp2006Ws & Percent imperviousness from 2006 in watershed & & & $\mathrm{X}$ & & & \\
\hline PctAgWs & Percent agricultural land cover in watershed & & & $\mathrm{X}$ & & & \\
\hline PctForRipWs & Percent riparian forest land cover in watershed & & & $\mathrm{X}$ & & & \\
\hline RunoffWs & Mean runoff in watershed & & & $\mathrm{X}$ & & & \\
\hline KffactWs & $\begin{array}{l}\text { The Kffactor-relative index of susceptibility of bare, } \\
\text { cultivated soil to particle detachment and transport by } \\
\text { rainfall in watershed }\end{array}$ & & & $X$ & & & \\
\hline PctClayWs & Percent clay content of soils in watershed & & & $\mathrm{x}$ & & & \\
\hline PctSandWs & Percent sand content of soils in watershed & & & $X$ & & & \\
\hline DamUNDR & $\begin{array}{l}\text { Upstream network dam density per unit stream } \\
\text { network length }(\# / 100 \mathrm{~km})\end{array}$ & & & & $X$ & & \\
\hline DamDMD & $\begin{array}{l}\text { Downstream mainstem dam density per unit } \\
\text { downstream mainstem length }(\# / 100 \mathrm{~km})\end{array}$ & & & & X & & \\
\hline HUC2PctFP & $\begin{array}{l}\text { Percent of mitigation sites in the mitigation database } \\
\text { within the HUC } 2 \text { that had Tier } 1 \text { fish passage } \\
\text { mitigation required }\end{array}$ & & & & $X$ & & \\
\hline
\end{tabular}


Table 1. Variables used in clustering analyses (continued).

\begin{tabular}{|c|c|c|c|c|c|c|c|}
\hline \multirow[b]{2}{*}{ Metric } & \multirow[b]{2}{*}{ Description (units) } & \multicolumn{6}{|c|}{ Module } \\
\hline & & 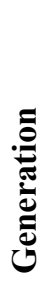 & 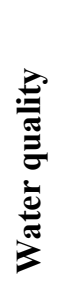 & 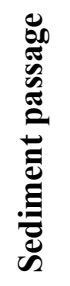 & 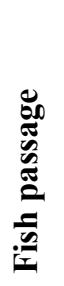 & 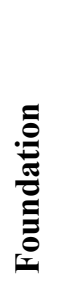 & 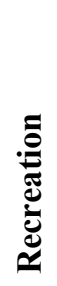 \\
\hline AnadAcip & $\begin{array}{l}\text { Number of ocean-run sturgeon species } \\
\text { (Acipenseriformes) within the reach's HUC8 (count) }\end{array}$ & & & & $\mathrm{x}$ & & \\
\hline PotAcip & $\begin{array}{l}\text { Number of inland sturgeon/paddlefish species } \\
\text { (Acipenseriformes) within the reach's HUC8 (count) }\end{array}$ & & & & $\mathrm{X}$ & & \\
\hline AnadClup & $\begin{array}{l}\text { Number of ocean-run clupeid species within the } \\
\text { reach's HUC8 (count) }\end{array}$ & & & & $\mathrm{X}$ & & \\
\hline EelsLamp & $\begin{array}{l}\text { Number of ocean-run eel/lamprey species within the } \\
\text { reach's HUC8 (count) }\end{array}$ & & & & $\mathrm{X}$ & & \\
\hline AnadSalm & $\begin{array}{l}\text { Number of ocean-run salmonid species within the } \\
\text { reach's HUC8 (count) }\end{array}$ & & & & $\mathrm{X}$ & & \\
\hline PotSalm & $\begin{array}{l}\text { Number of inland salmonid species within the reach's } \\
\text { HUC8 (count) }\end{array}$ & & & & $\mathrm{x}$ & & \\
\hline PotOthr & $\begin{array}{l}\text { Number of other inland migratory species within the } \\
\text { reach's HUC8 }\end{array}$ & & & & $\mathrm{X}$ & & \\
\hline PowerQS & Measure of stream power (mean annual flow x slope) & & & & & $\mathrm{X}$ & \\
\hline UCSLow & Low value for range of unconsolidated rock score & & & & & $\mathrm{X}$ & \\
\hline UCSHigh & High value for range of unconsolidated rock score & & & & & $\mathrm{X}$ & \\
\hline GrndAccel & Earthquake susceptibility & & & & & $\mathrm{X}$ & \\
\hline Fishing_Salt & Saltwater fishing locations in HUC6 (count) & & & & & & $\mathrm{X}$ \\
\hline NRIRecHUC6KM & $\begin{array}{l}\text { Length of stream identified as having outstanding } \\
\text { recreational value in the National Rivers Inventory } \\
\text { (m) }{ }^{1}\end{array}$ & & & & & & $\mathrm{X}$ \\
\hline AWHUC6KM & $\begin{array}{l}\text { Length of stream identified as American Whitewater } \\
\text { paddling runs }(\mathrm{m})\end{array}$ & & & & & & $\mathrm{X}$ \\
\hline Boat_Ramp_Un & Number of undeveloped boat ramps in HUC6 (count) & & & & & & $\mathrm{X}$ \\
\hline Boat_Ramp & Number of developed boat ramps in HUC6 (count) & & & & & & $\mathrm{X}$ \\
\hline PopDns10HUC6 & Mean population density in HUC6 & & & & & & $\mathrm{X}$ \\
\hline PopDns10CAT & Mean population density in stream reach catchment & & & & & & $\mathrm{X}$ \\
\hline Fishing Cold & $\begin{array}{l}\text { Number of cold-water fishing locations in HUC6 } \\
\text { (count) }\end{array}$ & & & & & & $\mathrm{X}$ \\
\hline
\end{tabular}

\subsection{MODULE-SPECIFIC CLASSIFICATION CATEGORIES}

\subsubsection{Generation}

The primary objective of classifying sites based on generation potential relies on understanding the ability of the stream to supply adequate flow, velocity, and head to produce a viable source of hydropower. This analysis is not intended to be a detailed resource assessment but only to provide a very broad classification. For the clustering analysis, we included variables that were related to or that characterized (1) the amount of water in a reach (QA_MA, RunoffWs, IEOFCAT), (2) temporal aspects of the hydrograph (QA_CV, BFICAT), and (3) the potential energy associated with the stream (SLOPE, VA_MA, ElevDiffWS) (Table 1). Fine-scale information (i.e., hourly or daily) on flow variability is not 
readily available by NHD reach, so we calculated a flow coefficient of variation based on mean monthly averages to at least include seasonal variations in flow in the analysis.

\subsubsection{Water Quality}

The primary objective of classifying sites to inform the need for a water quality module is to group sites of similar existing or future water quality and water quality risk. We included variables that were related to or characterized (1) indicators of existing compromised water quality (i.e., PctAgWs, PctImp2006Ws, PctImp2006Cat, PctAgCat, FarmNCat, PopDns10Cat), (2) land cover characteristics that affect water quality (KffactWs, KffactCat, PctForWetWs, PctForWetCat), and (3) instream water quantity (i.e., QA_MA, IEOFCat) (Table 1).

\subsubsection{Sediment Passage}

The primary objective of classifying sites to inform the need for a sediment transport module was to understand if there will likely be a need or desire to pass sediment and, if so, what kind of sediment, how much and when. We therefore included variables that were related to or characterized (1) the quality and quantity of sediment in the stream (i.e., RckDepCat, PctClayWs, PctSandWs), (2) the ability of the stream to transport sediment (i.e., QA_MA, Slope, VA_MA), (3) watershed impacts on sediment transport (PctImp2006Ws, PctAgWs, PctForRipWs, RunoffWs, KffactWs), and (4) the temporal aspects of sediment transport dynamics (i.e., QA_CV) (Table 1).

Because direct sediment transport data are generally not available at the level of national coverage, we are also pursuing an alternate approach with the University of Tennessee's Water Resources Research Center that includes a more mechanistic understanding of the hydrodynamics of stream geomorphology and sediment transport. If successful, this effort will result in a suite of variables that can be used in a clustering analysis, which are more closely related to specific sediment type and transport hydrology.

\subsubsection{Fish Passage}

To determine if an upstream or downstream fish passage module is needed, it is important to know whether fish are present that would normally pass through the site and, if so, what their life stages are and when, how frequently, and how they can pass (for example by spill, through a turbine, or by way of ladder or bypass). The primary objective of classifying sites based on fish passage need was to include variables that characterized or were related to (1) existing barriers in the stream network (DamUNDR, DamDMD), (2) the existence of passage mitigation at nearby hydropower dams (i.e., HUC2PctFP), and (3) the presence and absence of various migratory fish species (i.e., AnadAcip, PotAcip, AnadClup, EelsLamp, AnadSalm, PotSalm, PotOthr) (Table 1).

\subsubsection{Foundation}

To better understand what type of foundation module might be needed, we need to know something about the stability of the river geomorphology and the water flow forces that are present. The primary objective of classifying sites based on foundation need was to include variables that were related to or useful for characterizing (1) streambed morphology (RckDepCat), (2) erodibility of local soil and rock (UCSLow, UCSHigh), (3) water force that would be experienced by an in-river structure (QA_MA, Slope, VA_MA, PowerQS), and (4) a measure of earthquake instability or risk (GrndAccel) (Table $\overline{1}$ ). 


\subsubsection{Recreation}

To better understand the possible need for and purpose of a recreation support module, we need to know something about the types of river-related recreation that are presently supported in the region and the potential for new recreational opportunities - including the number of people that might take advantage of them. The primary objective of classifying sites based on recreation need was to include variables that were related to or characterized (1) the present status of recreation in the region (Fishing_Salt, NRIRecHUC6KM, AWHUC6KM, Boat_Ramp_Un, Boat_Ramp, Fishing_Cold), (2) the numbers of active or potential recreation users (PopDns10HUC6, PopDns10CAT), and (3) river size (QA_MA, Slope) (Table 1). 


\section{RESULTS}

\subsection{GENERATION}

Of the initial 304,035 NHD stream reaches, 264,180 were grouped into 10 clusters based on similarities in the amount of water in a reach, temporal aspects of the hydrograph, and potential energy associated with the stream. Table 2 shows how the NHD reaches are distributed among the ten clusters, what the defining characteristics of each cluster are, and where the reaches within a cluster are distributed geographically. Figure 1 illustrates the geographic distribution of the ten clusters. Six of the clusters (numbers 1, 2, 3, 7, 8, and 9) contain attributes that are correlated with viable hydropower development (e.g., some combination of high velocity, high baseflow, or steep gradient), and four of the clusters (numbers 4, 5, 6, and 10) are dominated by characteristics that are not favorable to development (e.g., low baseflow, low gradient, low velocity).

Most of the sites $(4,841$ of 8,$489 ; 57 \%)$ identified in ORNL's NSD analysis (NSD sites) are in reaches in clusters 3 and 8 (Figure 2). Similarly, 993 (61\%) of the 1,636 existing hydropower sites in the United States are in reaches contained in clusters $1,3,7$, and 8 . Clusters with a higher relative distribution of NSD sites or existing dams than the NHD reaches in the clusters might be considered more favorable to development, since their potential has been previously demonstrated. In the case of the generation analysis, using a criterion of a $>5 \%$ difference from the NHD distribution, we found that NSD sites were disproportionately distributed in clusters 2,3 , and 10; and existing dams were disproportionately distributed in reaches in clusters 3 and 8 . About $39 \%$ of NSD sites and $25 \%$ of existing dams are in cluster 3 stream reaches, which contain only $8 \%$ of the NHD stream reaches.

Table 2. Number and defining characteristics of stream reaches classified into ten different clusters as a result of K-means clustering analysis for generation potential.

\begin{tabular}{|c|c|c|c|}
\hline \# & $\begin{array}{c}\# \\
\text { Reaches }\end{array}$ & Defining characteristics & Locale \\
\hline 1 & 37,500 & $\begin{array}{l}\text { Low Q, high baseflow, high seasonal variability (snow } \\
\text { melt) }\end{array}$ & Rockies, Sierras \\
\hline 2 & 10,000 & $\begin{array}{l}\text { Med Q, steep grade, high baseflow, low seasonal } \\
\text { variability }\end{array}$ & Cascades \\
\hline 3 & 21,500 & Med Q, high velocity & National \\
\hline 4 & 9,000 & Med Q, low grade, low baseflow & Great Plains, Texas \\
\hline 5 & 18,000 & $\begin{array}{l}\text { Low Q, low grade, low baseflow, low velocity, high } \\
\text { seasonal variability }\end{array}$ & National, valleys and plains \\
\hline 6 & 69,000 & Low Q, low grade, low baseflow, low velocity & $\begin{array}{l}\text { Mississippi Valley, Midwest and } \\
\text { Midsouth }\end{array}$ \\
\hline 7 & 2,700 & Low Q, steep grade, high baseflow & Rockies, Sierras, Cascades \\
\hline 8 & 86,500 & High baseflow, low Q, moderate runoff, low velocity & $\begin{array}{l}\text { Great Lakes, Appalachians, Atlantic } \\
\text { Coast, West Coast foothills }\end{array}$ \\
\hline 9 & 20 & Med Q, very steep gradient, high velocity & - \\
\hline 10 & 9,500 & High Q, low grade & National \\
\hline
\end{tabular}




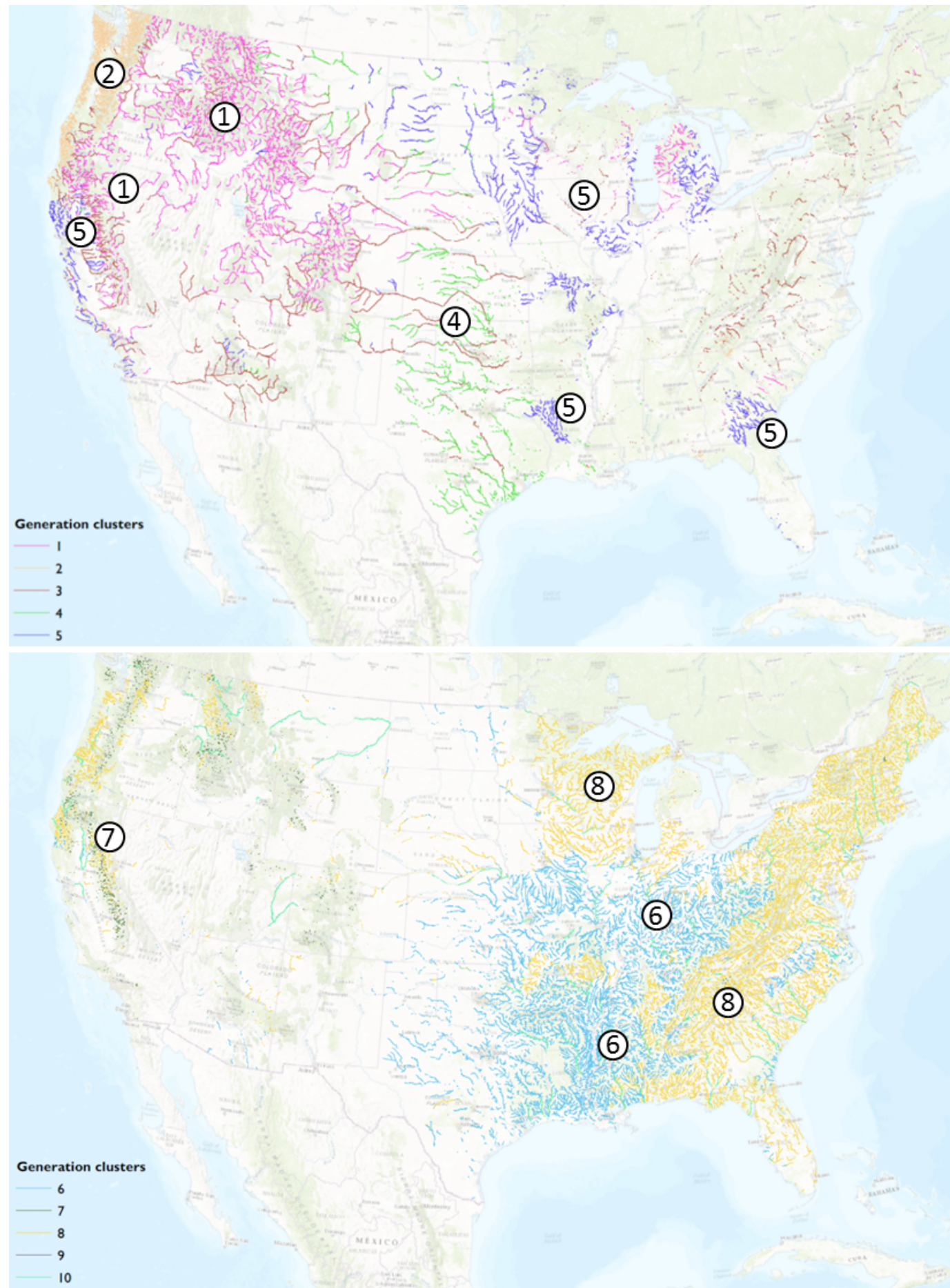

Figure 1. Maps of the k-means clusters 1 through 5 (top panel) and 6 through 10 (bottom panel) based on characteristics related to hydropower generation. Clusters not identified in the figures are either few in number or widely distributed. 

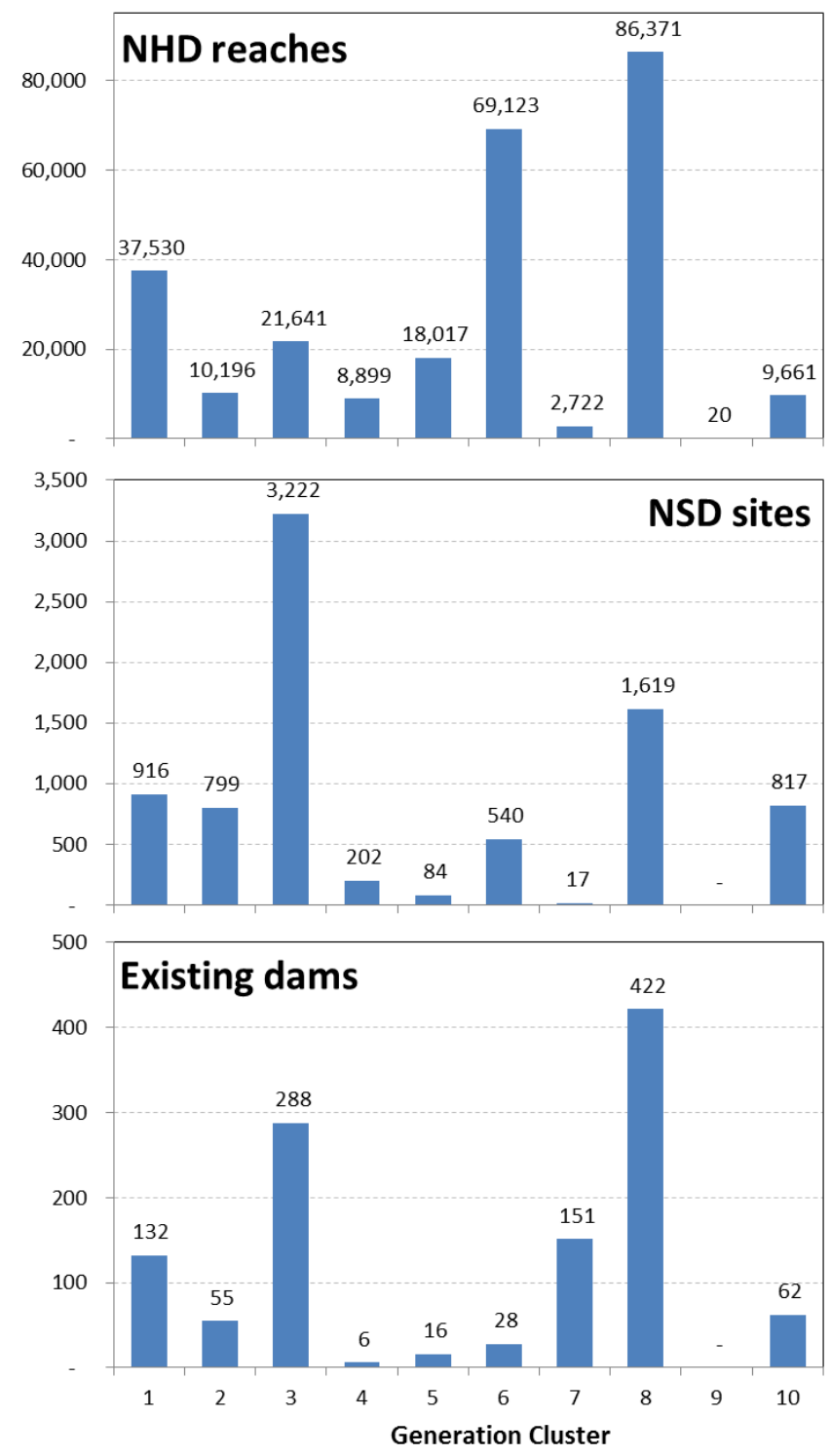

Figure 2. Count of US NHD stream reaches (1) in each of ten K-means generation clusters (top panel), (2) associated with identified NSD sites (middle panel), and 3) associated with existing hydropower dams (bottom panel). 


\subsection{WATER QUALITY}

Of the initial 304,035 NHD stream reaches, 252,709 were grouped into 10 clusters based on similarities in the amount of water in a reach, indicators of existing compromised water quality, and land cover characteristics that affect water quality (Table 3, Figure 3). Within this analysis, it is difficult to pre-select desirable or viable hydropower sites based on water quality. For example, high-gradient streams with high generation potential are often located in remote mountainous areas where water quality is generally very good. On the other hand, development in streams with already degraded water quality could result in fewer water quality concerns related to hydropower development

Most of the sites $(5,357$ of 8,$489 ; 63 \%)$ identified in ORNL's NSD analysis (NSD sites) are in reaches in clusters 1, 5, and 7 (Figure 4). Similarly, 1,219 (75\%) of the 1,636 existing hydropower sites in the United States are in reaches contained in clusters 1, 5, 7, and 9. Clusters with a higher relative distribution of NSD sites or existing dams than the NHD reaches in the clusters might be considered more favorable to development, since their potential has been previously demonstrated. In the case of the water quality analysis, using a criterion of a $>5 \%$ difference from the NHD distribution, we found that NSD sites were disproportionately distributed in clusters 1 and 4; and existing dams were disproportionately distributed in clusters 5 and 9 . About $43 \%$ of existing dams are in cluster 5 , which contains only $22 \%$ of the NHD stream reaches.

Table 3. Number and defining characteristics of stream reaches classified into ten different clusters as a result of K-means clustering analysis for water quality.

\begin{tabular}{rrll} 
\# & \multicolumn{1}{c}{$\begin{array}{c}\text { \# } \\
\text { Reaches }\end{array}$} & \multicolumn{1}{c}{ Defining characteristics } & \multicolumn{1}{c}{ Locale } \\
\hline 1 & 38,238 & Unforested, low agriculture, low erodibility & Plains \\
2 & 30,675 & Agricultural, high erodibility & Mississippi and Ohio River valleys \\
\hline 3 & 114 & Agricultural, nitrogen runoff & - \\
\hline 4 & 10,144 & Large rivers, & National \\
\hline 5 & 54,936 & Forested, low erodibility & National \\
\hline 6 & 40,053 & Agricultural, high erodibility, nitrogen runoff & $\begin{array}{l}\text { Midwest, Ohio and Mississippi River } \\
\text { valleys }\end{array}$ \\
\hline 7 & 59,040 & Forested, low agriculture, moderate erodibility & National \\
\hline 8 & 1,793 & Small streams, urban, impervious surfaces & National \\
\hline 9 & 7,509 & Suburban, impervious & \\
\hline 10 & 10,207 & Agricultural, unforested, nitrogen runoff & Great Plains \\
\hline
\end{tabular}




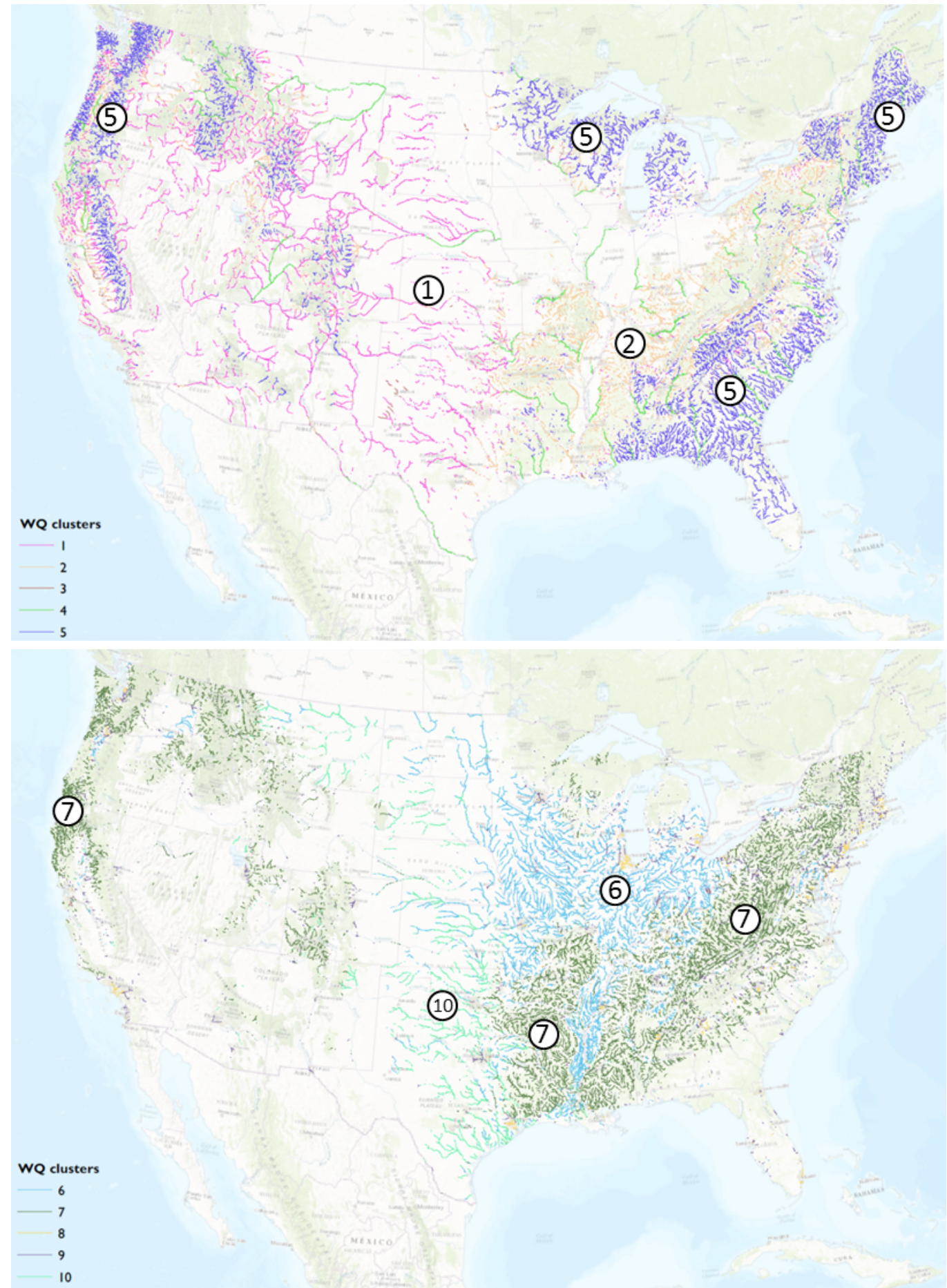

Figure 3. Maps of the k-means clusters 1 through 5 (top panel) and 6 through 10 (bottom panel) based on characteristics related to water quality. Clusters not identified in the figures are either few in number or widely distributed. 

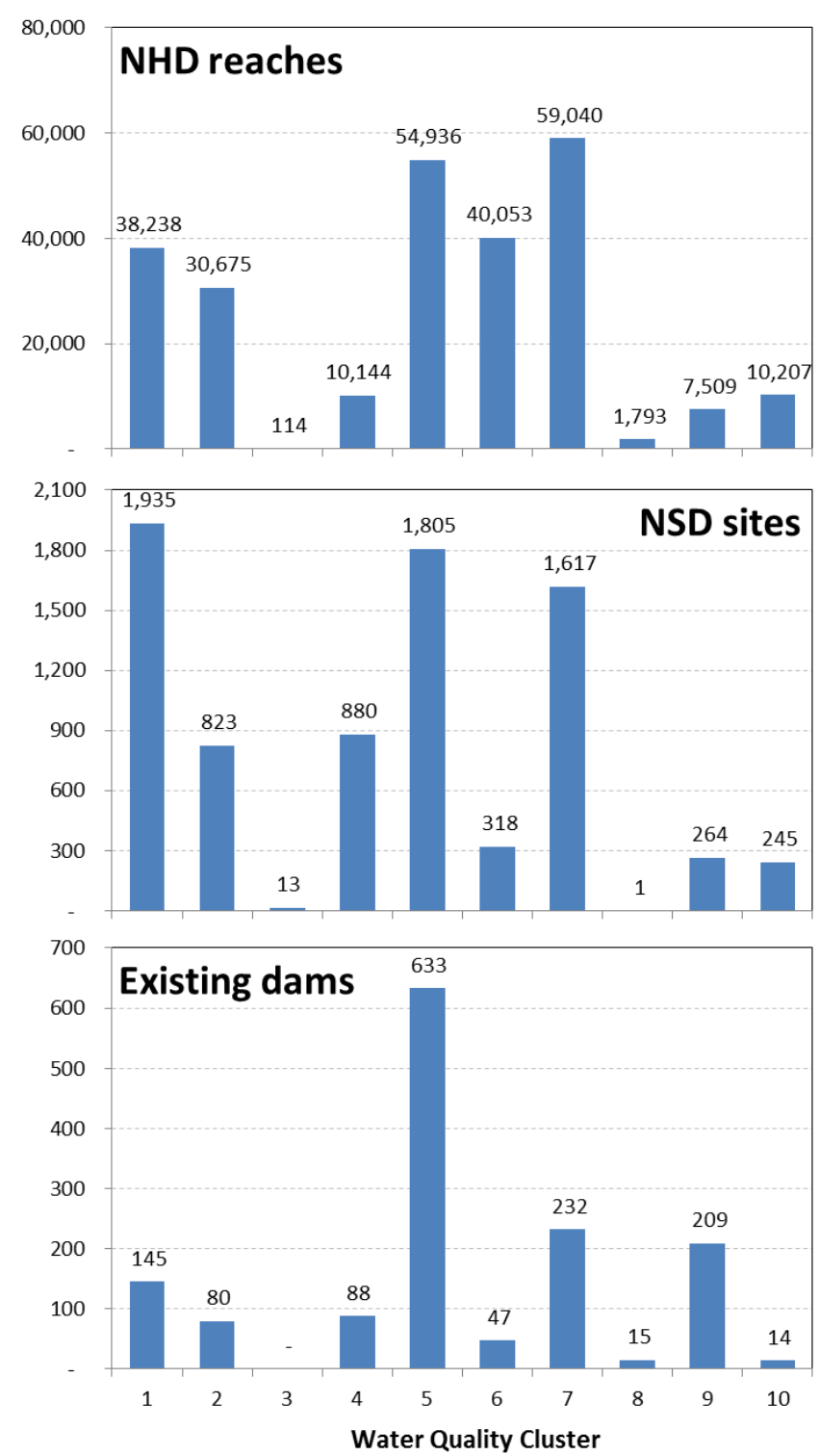

Figure 4. Count of US NHD stream reaches (1) in each of ten K-means water quality clusters (top panel), (2) associated with identified NSD sites (middle panel), and (3) associated with existing hydropower dams (bottom panel). 


\subsection{SEDIMENT PASSAGE}

Of the initial 304,035 NHD stream reaches, 271,170 were grouped into 10 clusters based on similarities in the quality and quantity of sediment in the stream, the ability of the stream to transport sediment, and watershed impacts on sediment load and transport (Table 4, Figure 5). Within this analysis, it is difficult to pre-select desirable or viable hydropower sites based on sediment passage. However, developers might prefer sites with little need for sediment transport - such as streams in heavily forested watersheds, highvelocity streams, and those with low agricultural input (e.g., clusters 2, 6, 7, and 10) or where sediment transport is easier to achieve, such as streams with fine suspended sediment or sand (e.g., clusters 3, 4, and 8) as opposed to coarse gravel and cobble.

Most of the sites $(5,014$ of 8,489; 59\%) identified in ORNL's NSD analysis (NSD sites) are in reaches in clusters 1, 6, and 7 (Figure 6). Similarly, $986(60 \%)$ of the 1,636 existing hydropower sites in the United States are in reaches contained in clusters $1,6,7,8$, and 9. Clusters with a higher relative distribution of NSD sites or existing dams than the NHD reaches in the clusters might be considered more favorable to development, since their potential has been previously demonstrated. In the case of the sediment passage analysis, using a criterion of a $>5 \%$ difference from the NHD distribution, we found that NSD sites were disproportionately distributed in clusters 1,9 and 10; and existing dams were disproportionately distributed in clusters 6 and 9 . About $41 \%$ of existing dams are in cluster 6 , which contains only $15 \%$ of the NHD stream reaches.

Table 4. Number and defining characteristics of stream reaches classified into ten different clusters as a result of K-means clustering analysis for sediment passage.

\begin{tabular}{clll}
$\#$ & \multicolumn{1}{c}{$\begin{array}{c}\text { D } \\
\text { Reaches }\end{array}$} & \multicolumn{1}{c}{ Defining characteristics } & \multicolumn{1}{c}{ Locale } \\
\hline 1 & 34,841 & Low runoff, variable flow & Mountain West and plains \\
2 & 81 & $\begin{array}{l}\text { Moderate steady flow, low ag, high runoff, high } \\
\text { velocity }\end{array}$ & \\
3 & 44,804 & Low velocity, clay & Upper Midwest \\
4 & 62,824 & Agricultural, slow, high erodibility, clay & Midsouth \\
5 & 3,592 & Small streams, slow, urban & National \\
6 & 40,154 & Forested, low ag & Northeast, Northwest, Appalachians \\
7 & 32,939 & Rocky streams, forested & National \\
\hline 8 & 30,742 & Sandy, low erosion, slow & Southeast, Great Lakes \\
\hline 9 & 11,471 & Large rivers, high velocity & National \\
\hline 10 & 9,785 & Forested, low ag, high runoff, steady flow & Pacific Northwest \\
\hline
\end{tabular}



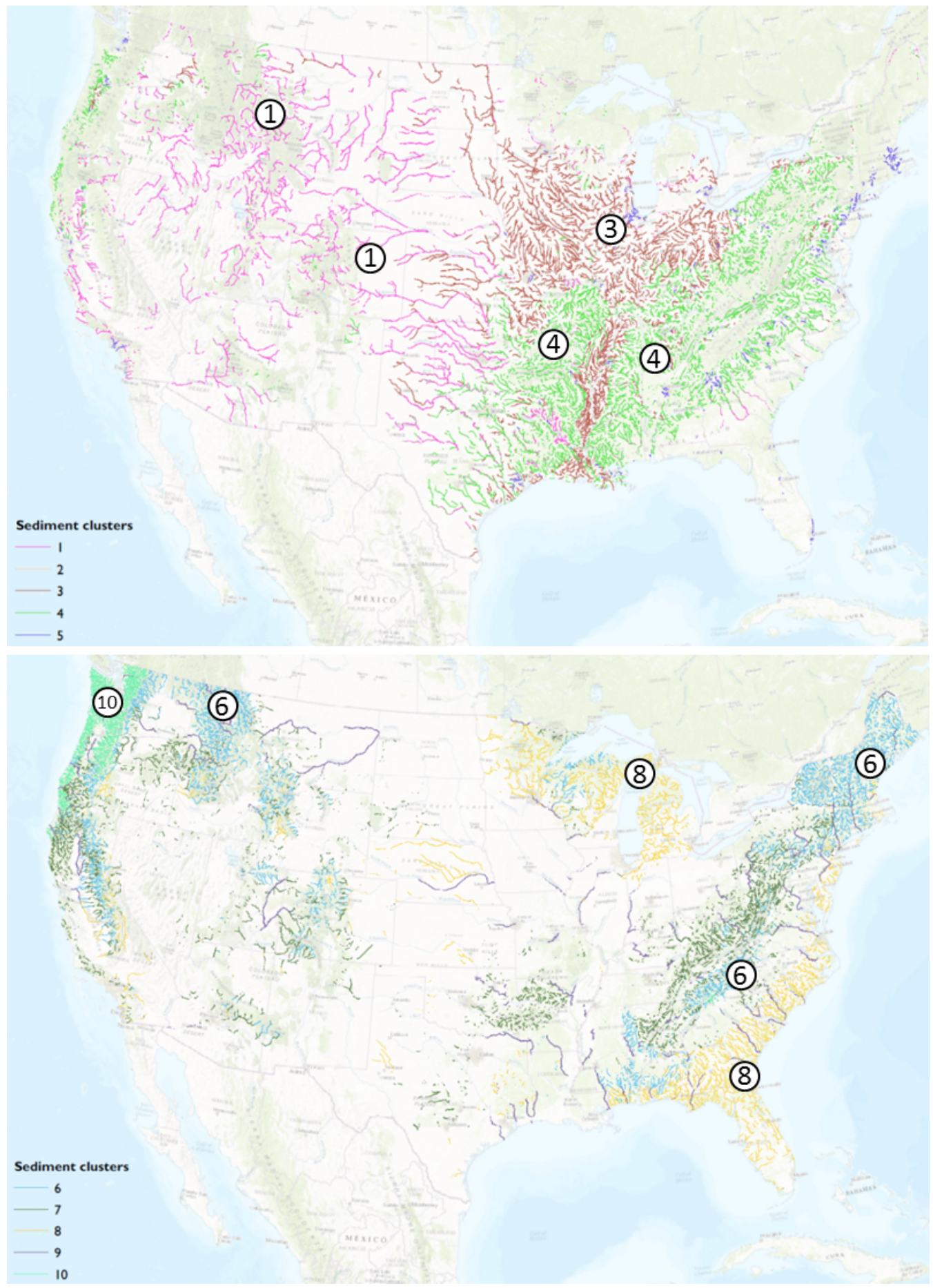

Figure 5. Maps of the k-means clusters 1 through 5 (top panel) and 6 through 10 (bottom panel) based on characteristics related to sediment passage. Clusters not identified in the figures are either few in number or widely distributed. 

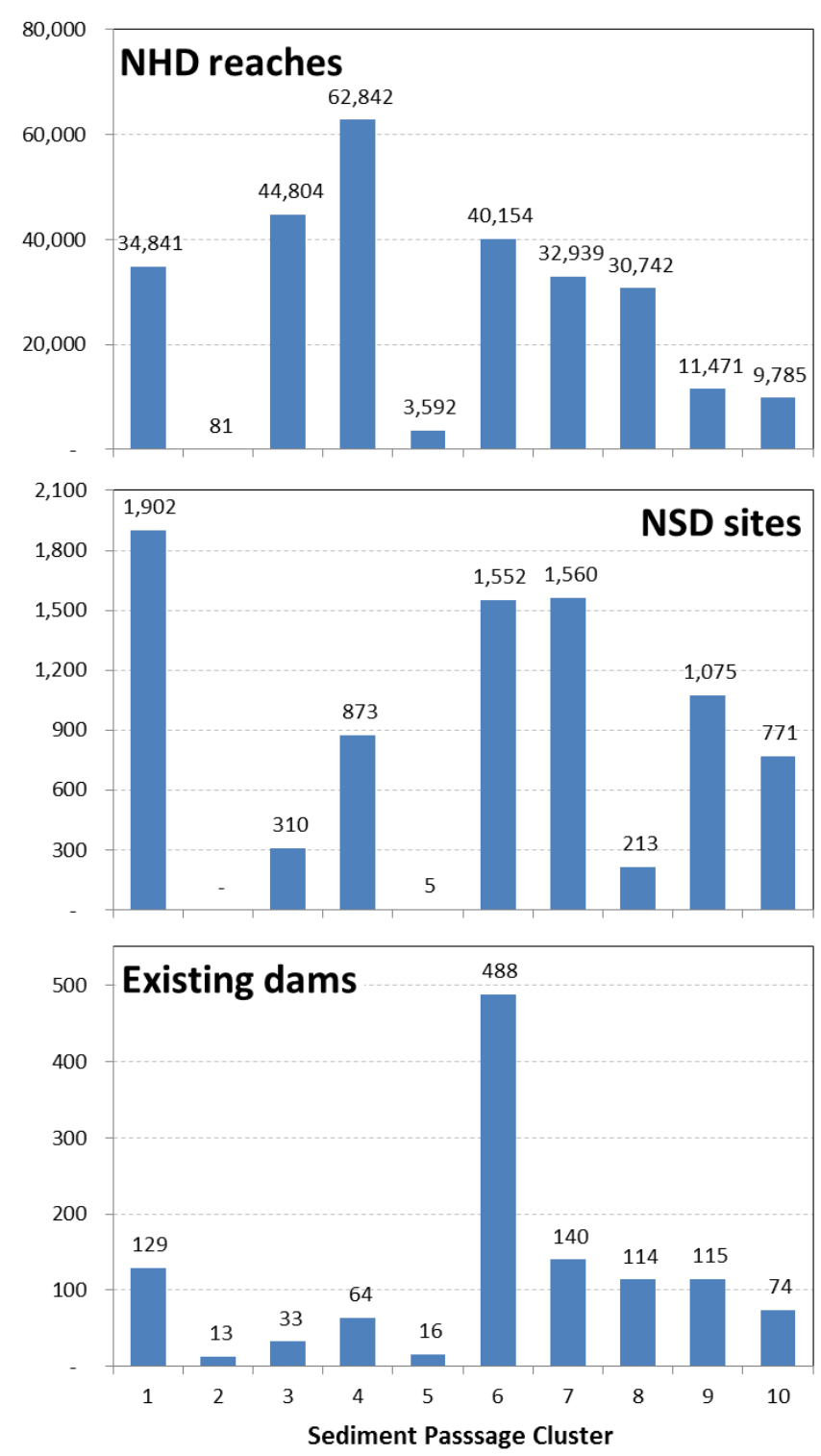

Figure 6. Count of US NHD stream reaches (1) in each of ten K-means sediment passage clusters (top panel), (2) associated with identified NSD sites (middle panel), and (3) associated with existing hydropower dams (bottom panel). 


\subsection{FISH PASSAGE}

Of the initial 304,035 NHD stream reaches, 261,134 were grouped into ten clusters based on similarities in the number of existing barriers in the stream network, the existence of passage mitigation at nearby hydropower dams, and the presence or absence of various migratory fish species (Table 5, Figure 7). Developers that prefer to avoid fish passage mitigation might favor clusters with low numbers of migratory fish species present, with many downstream dams that already prevent anadromous fish migration, and/or near existing licensed dams with minimal existing fish passage requirements, e.g., clusters 5,7 , and 9).

Most of the sites $(6,864$ of 8,$489 ; 81 \%)$ identified in ORNL's NSD analysis (NSD sites) are in reaches in clusters 1, 2, 3, and 7 (Figure 8). Similarly, 885 (54\%) of the 1,636 existing hydropower sites in the United States are in reaches contained in clusters 1,2, 7, and 10. Clusters with a higher relative distribution of NSD sites or existing dams than the NHD reaches in the clusters might be considered more favorable to development, since their potential has been previously demonstrated. In the case of the fish passage analysis, using a criterion of a $>5 \%$ difference than the NHD distribution, we found that NSD sites were disproportionately distributed in clusters 1,3 and 6; and existing dams were disproportionately distributed in clusters 1,2 , and 10.

Table 5. Number and defining characteristics of stream reaches classified into ten different clusters as a result of K-means clustering analysis for fish passage.

\begin{tabular}{|c|c|c|c|}
\hline \# & $\begin{array}{c}\# \\
\text { Reaches }\end{array}$ & Defining characteristics & Locale \\
\hline 1 & 41,002 & $\begin{array}{l}\text { Potamodromous salmonids, high downstream dam } \\
\text { count, high existing passage mitigation }\end{array}$ & Appalachia, Texas, Northwest \\
\hline 2 & 48,378 & $\begin{array}{l}\text { High other potamodromous species, low anadromous } \\
\text { species }\end{array}$ & $\begin{array}{l}\text { Great Lakes, upper Midwest, upper } \\
\text { Ohio River, Gulf Coast }\end{array}$ \\
\hline 3 & 17,218 & $\begin{array}{l}\text { Anadromous salmonids, potamodromous salmonids, } \\
\text { low upstream and downstream dam count, high } \\
\text { existing passage mitigation, anadromous lampreys }\end{array}$ & Pacific Northwest \\
\hline 4 & 10,446 & $\begin{array}{l}\text { Some anadromous clupeids, high upstream and } \\
\text { downstream dam count, low MAF }\end{array}$ & South central \\
\hline 5 & 19,626 & $\begin{array}{l}\text { Low existing passage mitigation, low or absent } \\
\text { salmonid presence, eels, low downstream dam count }\end{array}$ & Lower Mississippi River drainage \\
\hline 6 & 7,731 & High MAF, inland sturgeon, and other inland species & Scattered nationally \\
\hline 7 & 94,507 & $\begin{array}{l}\text { Very low numbers of all major migratory species, low } \\
\text { existing passage mitigation }\end{array}$ & Scattered nationally \\
\hline 8 & 2 & - & - \\
\hline 9 & 8,467 & $\begin{array}{l}\text { Inland sturgeons and other inland potamodromous } \\
\text { species, low downstream dam count, low existing } \\
\text { passage mitigation, low anadromous species }\end{array}$ & Upper Mississippi River drainage \\
\hline 10 & 13,757 & $\begin{array}{l}\text { Anadromous clupeids, ocean-run sturgeons, eels, high } \\
\text { upstream and downstream dam count, }\end{array}$ & Atlantic Coast \\
\hline
\end{tabular}




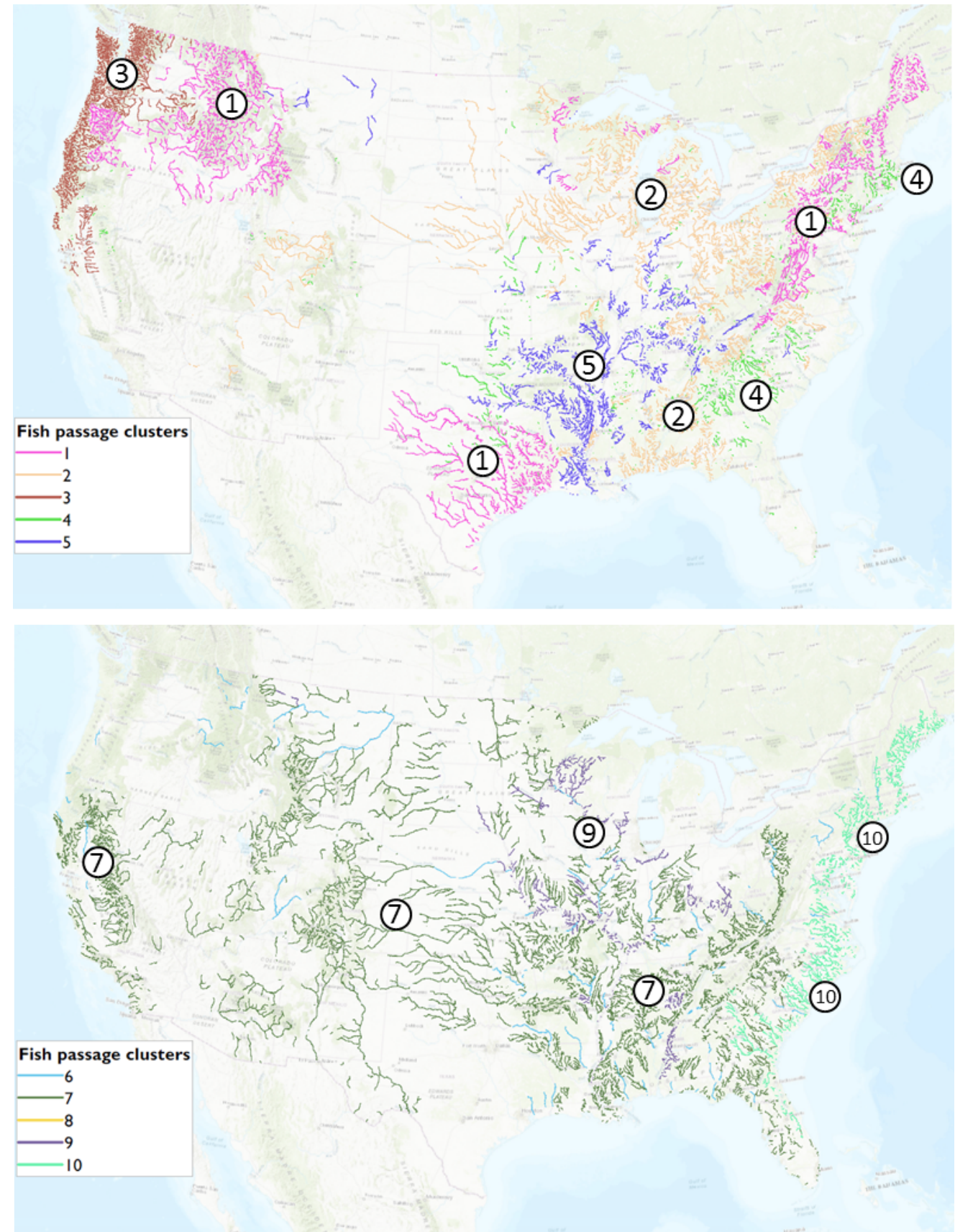

Figure 7. Maps of the k-means clusters 1 through 5 (top panel) and 6 through 10 (bottom panel) based on characteristics related to fish passage. Clusters not identified in the figures are either few in number or widely distributed. 

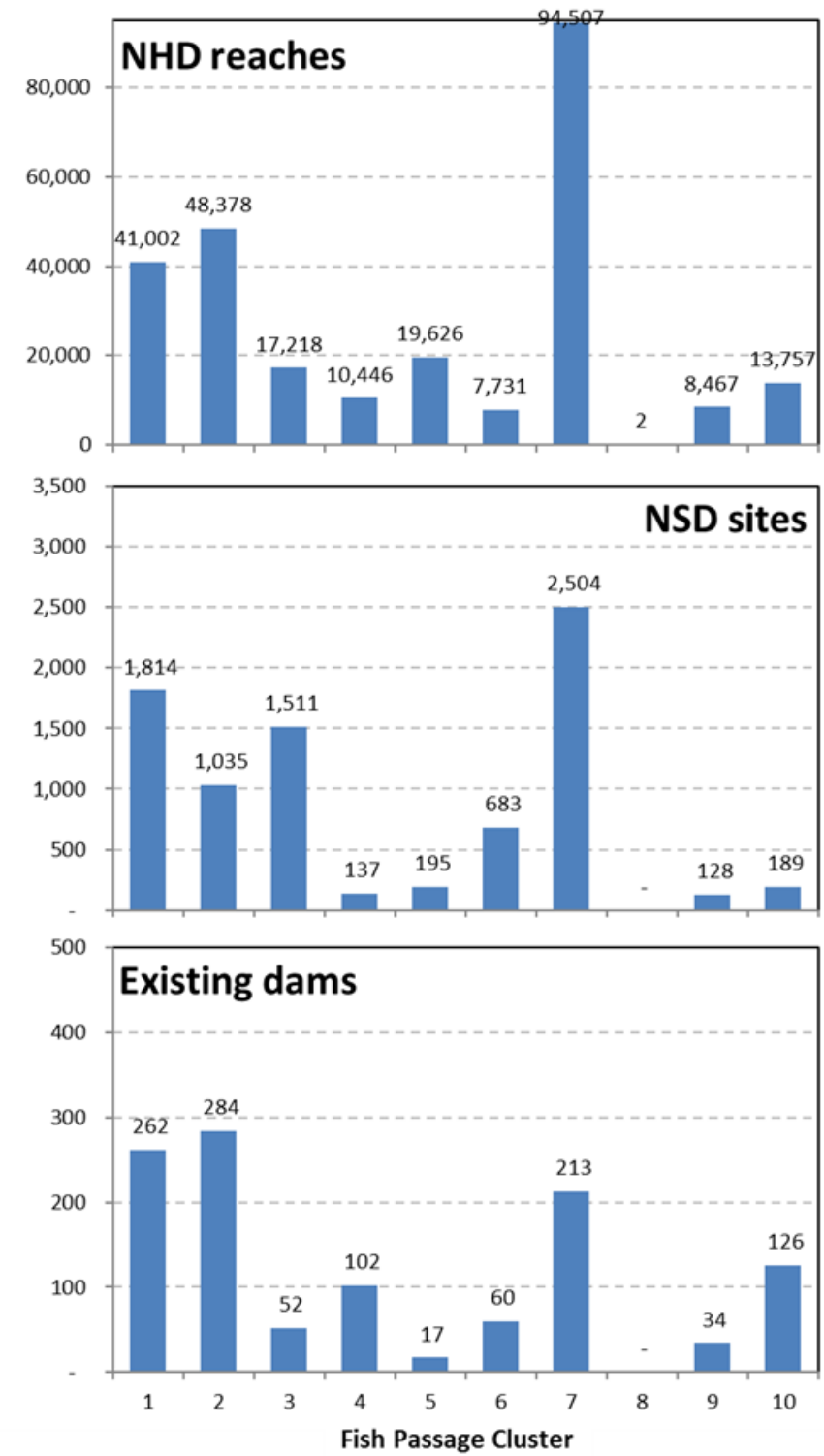

Figure 8. Count of US NHD stream reaches (1) in each of ten K-means fish passage clusters (top panel), (2) associated with identified NSD sites (middle panel), and (3) associated with existing hydropower dams

(bottom panel). 


\subsection{FOUNDATION}

Of the initial 304,035 NHD stream reaches, 271,271 were grouped into 10 clusters based on similarities in the hydrology (flow and velocity), depth to bedrock, risk of earthquake disturbance, and stream power (Table 6, Figure 9). Sites in the cluster defined by potential earthquake severity (i.e., cluster 3) would likely require additional consideration of dam safety in assessing foundational support, as would those with higher flows and higher velocities (i.e., clusters 5, 7, 8, and 10). Those reaches where depth to bedrock is shallow (i.e., clusters 1 and 7) would likely require different foundation anchoring from those where the bedrock is relatively deep (i.e., clusters $2,4,6$, and 8).

Most of the sites $(5,960$ of 8,$489 ; 70 \%)$ identified in ORNL's NSD analysis (NSD sites) are in reaches in clusters 1, 5, 7, and 8 (Figure 10). Similarly, 872 (53\%) of the 1,636 existing hydropower sites in the United States are in reaches contained in clusters 4, 7, 8, and 9. Clusters with a higher relative distribution of NSD sites or existing dams than the NHD reaches in the clusters might be considered more favorable to development, since their potential has been previously demonstrated. In the case of the foundation analysis, using a criterion of a $>5 \%$ difference from the NHD distribution, we found that NSD sites were disproportionately distributed in clusters 5 and 8; and existing dams were disproportionately distributed in clusters 7,8 , and 9 .

Table 6. Number and defining characteristics of stream reaches classified into ten different clusters as a result of K-means clustering analysis for project foundation.

\begin{tabular}{|c|c|c|c|}
\hline \# & $\begin{array}{c}\# \\
\text { Reaches }\end{array}$ & Defining characteristics & Locale \\
\hline 1 & 34,133 & Low flow, shallow bedrock, & $\begin{array}{l}\text { Low mountain streams: foothills of } \\
\text { Appalachia, Ozark, Sierras, etc. }\end{array}$ \\
\hline 2 & 43,474 & Low power, low flow, low gradient, deep bedrock & $\begin{array}{l}\text { Lowlands: Glaciated Great Lakes, } \\
\text { Upper Mississippi }\end{array}$ \\
\hline 3 & 12,912 & Highest earthquake hazard, high erodibility & $\begin{array}{l}\text { Pacific Coast, New Madrid fault, } \\
\text { South Carolina coast }\end{array}$ \\
\hline 4 & 42,554 & $\begin{array}{l}\text { Low power, low erodibility, low flow, low gradient, } \\
\text { deep bedrock }\end{array}$ & $\begin{array}{l}\text { Lowlands: Midwest, Northeast, and } \\
\text { Southeast }\end{array}$ \\
\hline 5 & 10,110 & High flow, high power, high velocity & Large rivers: national \\
\hline 6 & 75,378 & $\begin{array}{l}\text { Low power, high erodibility, low flow, low gradient, } \\
\text { deep bedrock }\end{array}$ & $\begin{array}{l}\text { Lowlands: Southeast and Gulf Coast, } \\
\text { Central Valley California }\end{array}$ \\
\hline 7 & 20,837 & $\begin{array}{l}\text { Moderately high power, high velocity, low erodibility, } \\
\text { shallow bedrock }\end{array}$ & $\begin{array}{l}\text { Foothill streams: Pacific Northwest, } \\
\text { Rockies, Appalachians, Maine }\end{array}$ \\
\hline 8 & 29,151 & $\begin{array}{l}\text { High erodibility, high flow, moderately high velocity, } \\
\text { deep bedrock }\end{array}$ & National \\
\hline 9 & 2,644 & $\begin{array}{l}\text { Low erodibility, very high power, shallow bedrock, } \\
\text { high gradient, moderately high velocity }\end{array}$ & - \\
\hline 10 & 78 & $\begin{array}{l}\text { Low erodibility, high flow, very high gradient, very } \\
\text { high velocity }\end{array}$ & - \\
\hline
\end{tabular}




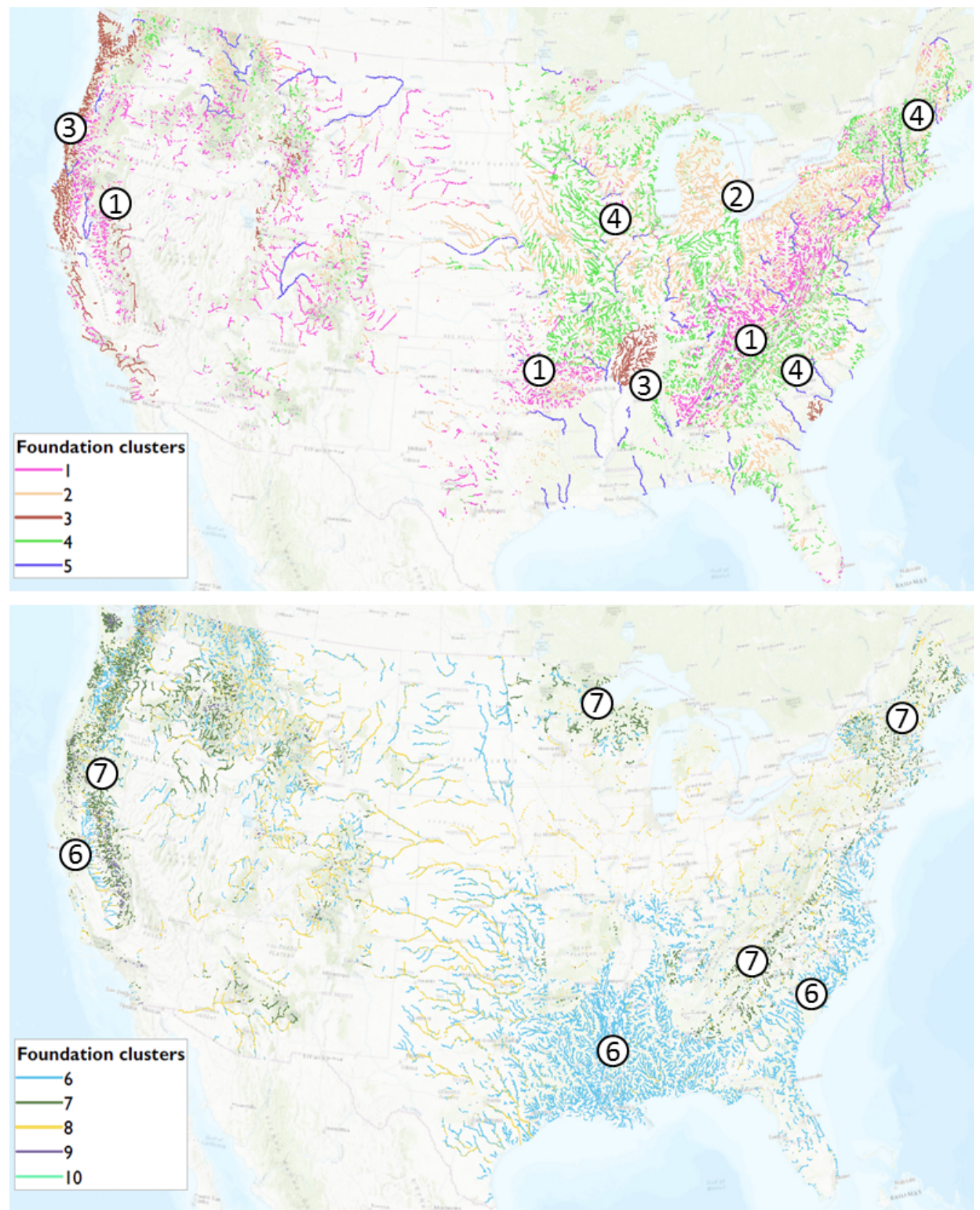

Figure 9. Maps of the k-means clusters 1 through 5 (top panel) and 6 through 10 (bottom panel) based on characteristics related to foundational support. Clusters not identified in the figures are either few in number or widely distributed. 

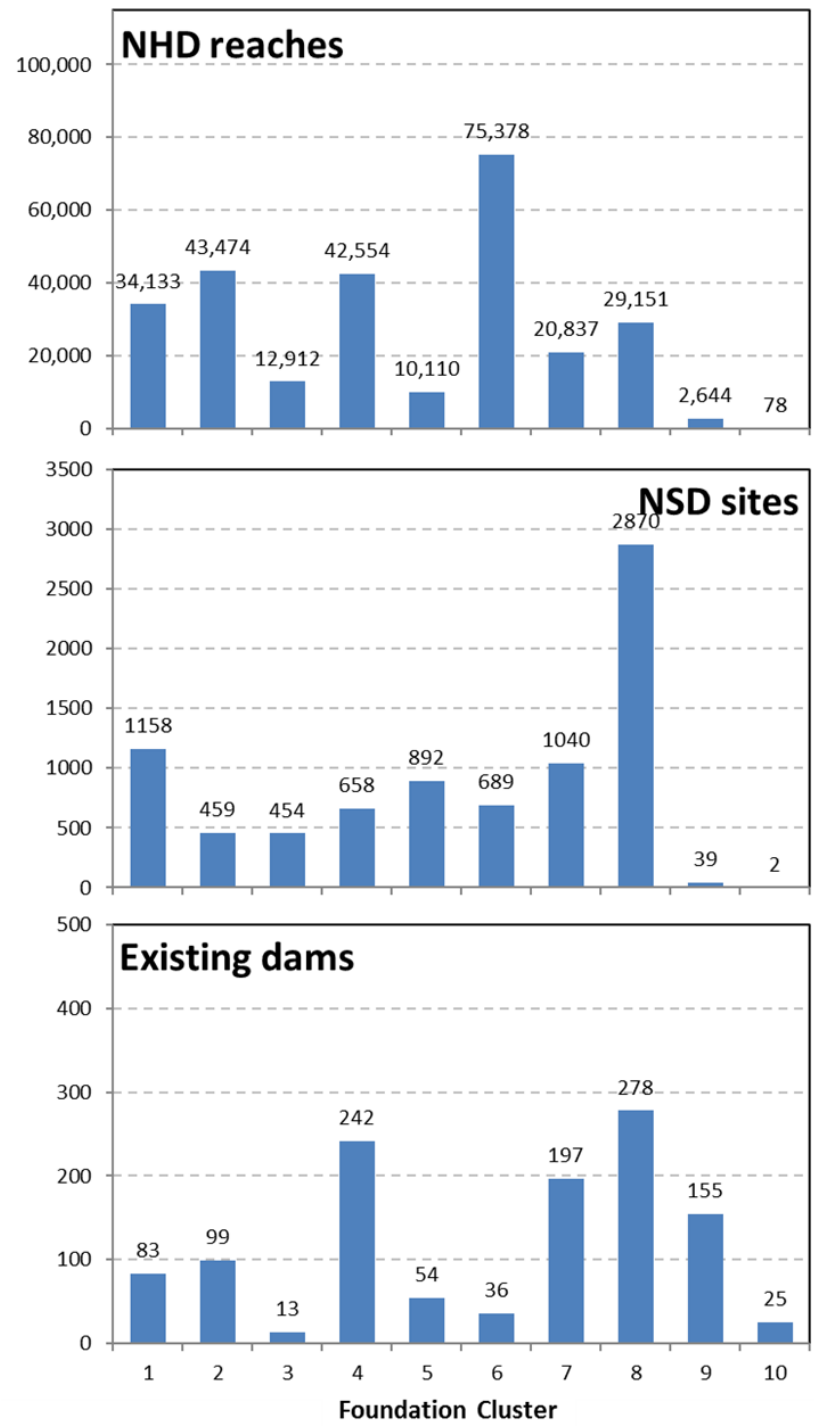

Figure 10. Count of US NHD stream reaches (1) in each of ten K-means foundation clusters (top panel), (2) associated with identified NSD sites (middle panel), and (3) associated with existing hydropower dams (bottom panel). 


\subsection{RECREATION}

Of the initial 304,035 NHD stream reaches, 301,472 were grouped into 10 clusters based on similarities in indicators of existing recreational resources (i.e., boat ramps, recognized whitewater sections, designated recreation and fishing reaches), proximity to user populations, river flow, and stream gradient (Table 7, Figure 11). One might expect that clusters defined by high levels of existing river recreation would likely require a module to maintain such services (i.e., clusters 4, 6, 7, and 8), whereas those with low present recreation might have less need (i.e., clusters 2, 9, and 10). On the other hand, clusters low in recreation but near population centers (i.e., clusters 2 and 3) might be perfect candidates for the creation of new recreational opportunities (e.g., whitewater parks) as part of "co-development" with hydropower.

Most of the sites (7,023 of 8,489; 83\%) identified in ORNL's NSD analysis (NSD sites) are in reaches in clusters 4, 9, and 10 (Figure 12). Similarly, 1,163 (71\%) of the 1,636 existing hydropower sites in the United States are in reaches contained in clusters 4, 7, and 10. Clusters with a higher relative distribution of NSD sites or existing dams than the NHD reaches in the clusters might be considered more favorable to development, since their potential has been previously demonstrated. In the case of the recreation analysis, using a criterion of a $>5 \%$ difference from the NHD distribution, we found that NSD sites were disproportionately distributed in clusters 4 and 9; and existing dams were disproportionately distributed in clusters 3 and 7.

Table 7. Number and defining characteristics of stream reaches classified into ten different clusters as a result of K-means clustering analysis for recreation.

\begin{tabular}{|c|c|c|c|}
\hline$\#$ & $\begin{array}{c}\# \\
\text { Reaches }\end{array}$ & Defining characteristics & Locale \\
\hline 1 & 10,788 & $\begin{array}{l}\text { Marine species fishing, small streams, limited boat } \\
\text { access }\end{array}$ & Atlantic, Pacific, and Gulf coasts \\
\hline 2 & 1,669 & Urban streams & National \\
\hline 3 & 7,464 & Suburban, small streams, cold-water fishing & National \\
\hline 4 & 42,225 & High whitewater use, cold-water fishing & $\begin{array}{l}\text { Appalachians, Sierras, and Rocky } \\
\text { Mountains }\end{array}$ \\
\hline 5 & 6 & $\begin{array}{l}\text { High gradient, low population density, limited boat } \\
\text { access, cold-water fishing }\end{array}$ & - \\
\hline 6 & 39,195 & High recreational preservation value, low gradient & Mid-central, Southeast, far Northwest \\
\hline 7 & 24,667 & Low gradient, high boat access, some whitewater & $\begin{array}{l}\text { Maine, Wisconsin, Minnesota, and } \\
\text { Arkansas }\end{array}$ \\
\hline 8 & 3,454 & $\begin{array}{l}\text { Marine species fishing, high recreational preservation } \\
\text { value, high whitewater use, high boat access, cold- } \\
\text { water fishing }\end{array}$ & Puget Sound \\
\hline 9 & 12,598 & Large rivers, low gradient & National \\
\hline 10 & 159,406 & Rural, limited boat access, low gradient & $\begin{array}{l}\text { Ohio and Mississippi River valleys, } \\
\text { eastern Great Lakes, Great Plains }\end{array}$ \\
\hline
\end{tabular}



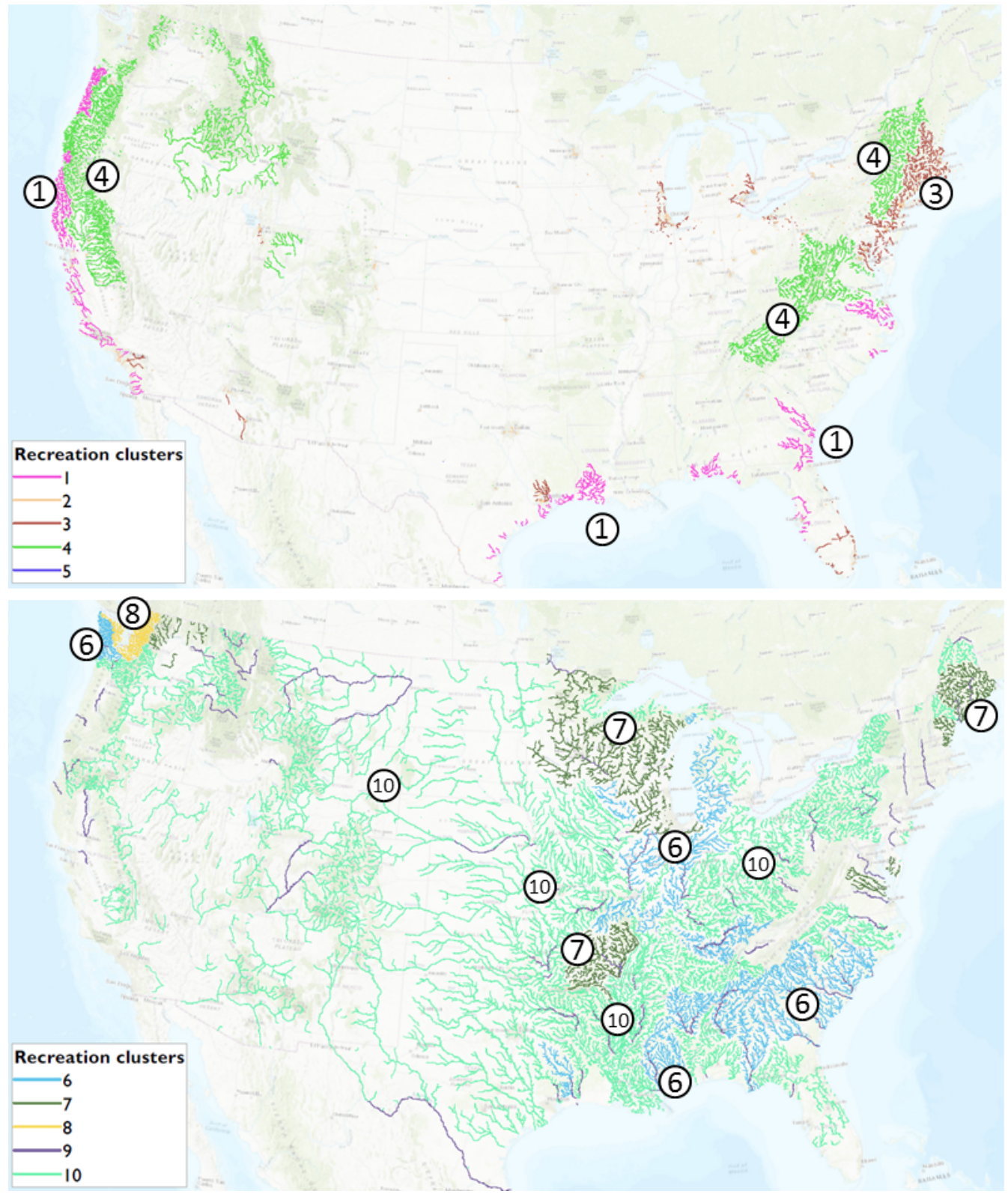

Figure 11. Maps of the k-means clusters 1 through 5 (top panel) and 6 through 10 (bottom panel) based on characteristics related to supporting recreation uses. Clusters not identified in the figures are either small in number or widely distributed. 

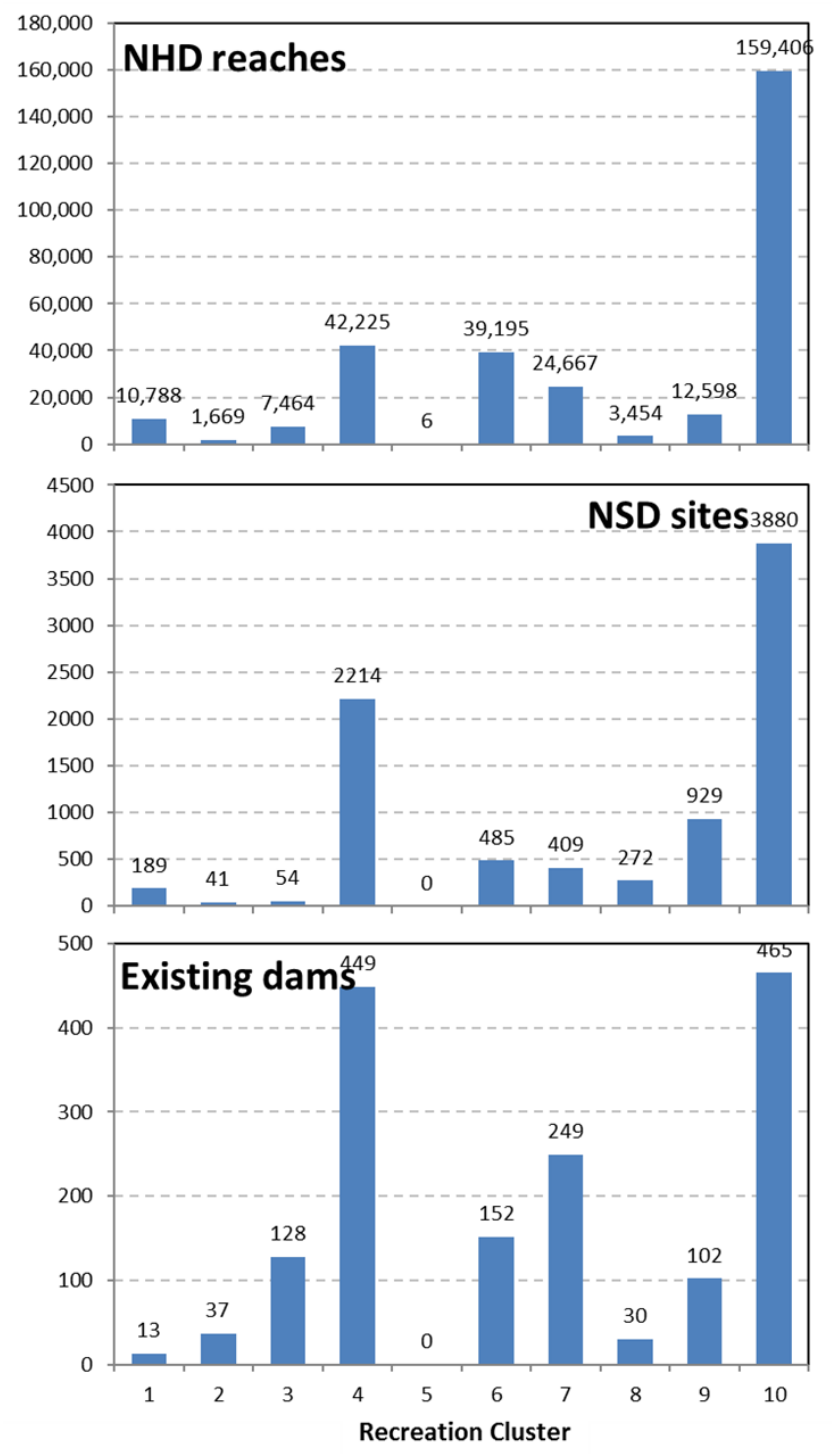

Figure 12. Count of US NHD stream reaches (1) in each of ten K-means recreation clusters (top panel), (2) associated with identified NSD sites (middle panel), and (3) associated with existing hydropower dams (bottom panel). 


\section{DISCUSSION}

The results of the site classification analyses are summarized in a searchable Excel spreadsheet and in a soon-to-be-released, geospatial, web-based tool called SMH Explorer. Both formats will include for each of the $300,000+$ NHD reaches the following information:

- the cluster number (1 to 10) for each of the six module classifications completed to date

- the value of the key variables that went into the clustering analysis (e.g., mean annual flow, percentage of impervious surfaces in the watershed, presence of anadromous salmon)

- the length of each reach

- presence of existing dams in the reach (and generation capacity)

- presence of NSD sites in the reach

The online SMH Explorer, which is presently undergoing beta testing, is intended for SMH module developers, SMH project developers, and environmental regulators. The intended uses of the tool might vary depending on user group.

\section{Module developers}

- Application space-A module developer might want to know how much opportunity there is for a particular module design. This could be useful for pre-development decision-making and postdevelopment marketing. Example: How many sites or how big an area might benefit from a fish passage module that passes a particular species group?

- Module design questions - A module developer might want to know the range of conditions within a certain type of project site. Example: What is the underlying geomorphology (e.g., sand or bedrock) for a particular region of particular stream size?

\section{Project developers}

- Module need-A project developer will want to know what modules (and functions) are likely to be needed for a site of interest. Example: Will sediment transport be necessary and, if so, what type and amount of sediment and how often?

- Issue avoidance-A developer might want to find sites where they can avoid certain issues. Example: For whatever reason, a developer might want to avoid the need to include a fish passage module.

- Issue attraction-A developer might have a reason to develop at sites with existing environmental issues. Example: A stream with low dissolved oxygen can present an opportunity to couple power generation with environmental improvement.

- Location centered-A developer might have a reason to develop within a specified region and want to know what opportunities and conditions are present.

- Similar development opportunity-A developer might have successfully developed a site and want to know where there are similar sites that could be approached in the same way.

\section{Regulators}

- Environmental issue identification-A regulator might want to quickly find information on other development within an area.

- Environmental conditions-A regulator might want to get a quick overview of the range of conditions and stream types relative to potential SMH development. 


\subsection{FUTURE GOALS}

1. We will continue to collaborate with expert faculty and associates in hydraulic design and sedimentation in the University of Tennessee-Knoxville (UTK) Department of Civil and Environmental Engineering to develop a list of variables for sediment transport classification that are more mechanistically related to sediment transport dynamics.

2. We will showcase research outcomes through the public release of SMH Explorer, a web-based environmental design platform for SMH facilities. The database that underlies this tool will be geospatially located so that all data query results can be produced as data tables for qualifying reaches and their attributes, or as maps of qualifying stream reaches. This tool will allow users to

a. drill down into individual clusters or combinations of clusters to better understand the application space (e.g., number of potential sites) of particular modular technologies

b. filter reaches to identify reaches for possible new development that have similar characteristics to already developed or developing sites

3. We will begin selecting variables and performing cluster analyses that are more specifically aimed at understanding specific design requirements. For example, a fish passage module, data, and analysis will be developed that can be used to group potential sites (i.e., stream reaches) based on migratory species' needs for specific fish ladder velocities and gradients. Table 8 provides an example of how some variables are useful for informing module need, others for design requirements, and some for both need and design. 
Table 8. Examples of classification data to be used to inform module need and module design requirements.

\begin{tabular}{|c|c|c|}
\hline Classification variable & Module need & Design requirements \\
\hline \multicolumn{3}{|c|}{ Downstream fish passage } \\
\hline $\begin{array}{l}\text { Anadromous/catadromous migratory species presence } \\
\text { - Timing of migrations/movements } \\
\text { - Size/life stage of migrants }\end{array}$ & $\mathrm{X}$ & $\mathrm{X}$ \\
\hline $\begin{array}{l}\text { Resident migratory species present } \\
\text { - Timing of migrations/movements } \\
\text { - Size/life stage of migrants }\end{array}$ & $X$ & $\mathrm{X}$ \\
\hline Stream gradient & & $\mathrm{X}$ \\
\hline Flow metrics & & $\mathrm{X}$ \\
\hline \multicolumn{3}{|c|}{ Upstream fish passage } \\
\hline $\begin{array}{l}\text { Migratory species presence } \\
\text { - Spatial and temporal }\end{array}$ & $X$ & \\
\hline $\begin{array}{l}\text { Resident species passage needs } \\
\text { - Spatial and temporal }\end{array}$ & $\mathrm{X}$ & \\
\hline Stream gradient & & $\mathrm{X}$ \\
\hline $\begin{array}{c}\text { Species' swimming abilities } \\
\text { - Prolonged velocity and duration } \\
\text { - } \quad \text { Burst velocity and duration }\end{array}$ & & $\mathrm{X}$ \\
\hline Species’ jumping abilities & & $\mathrm{X}$ \\
\hline Flow metrics & & $\mathrm{X}$ \\
\hline \multicolumn{3}{|c|}{ Sediment transport } \\
\hline Bedload characterization & $\mathrm{X}$ & \\
\hline Bedload movement & $\mathrm{X}$ & \\
\hline Stream gradient & & $\mathrm{X}$ \\
\hline $\begin{array}{l}\text { Watershed contribution to sediment load } \\
\text { - Soil type } \\
\text { - Soil erodibility }\end{array}$ & $\mathrm{X}$ & \\
\hline $\begin{array}{l}\text { Watershed land use } \\
\text { - Percent forested } \\
\text { - Percent agricultural (row crops) }\end{array}$ & $\mathrm{X}$ & \\
\hline $\begin{array}{ll}\text { Flow } & \\
\text { - } & \text { Mean annual } \\
\text { - Flood frequency }\end{array}$ & $\mathrm{X}$ & $\mathrm{X}$ \\
\hline \multicolumn{3}{|c|}{ Recreational boating } \\
\hline $\begin{array}{l}\text { Existing use } \\
\qquad \quad \text { Public access / launches }\end{array}$ & $\mathrm{X}$ & \\
\hline Local recreational boating vendors & $\mathrm{X}$ & \\
\hline $\begin{array}{l}\text { Flow metrics } \\
\qquad \quad \text { Seasonality (monthly quartiles) }\end{array}$ & $\mathrm{X}$ & $\mathrm{X}$ \\
\hline Gradient & & $\mathrm{X}$ \\
\hline Local population density & $\mathrm{X}$ & \\
\hline \multicolumn{3}{|c|}{ Water quality } \\
\hline $\begin{array}{l}\text { Existing water quality issues } \\
\text { - 303d listings }\end{array}$ & $\mathrm{X}$ & \\
\hline $\begin{array}{cl}\text { Water quality constituents } \\
\text { - } & \text { Nitrogen runoff } \\
\text { - } & \text { Phosphorus runoff } \\
\text { - } & \text { Turbidity }\end{array}$ & $\mathrm{X}$ & $\mathrm{X}$ \\
\hline $\begin{array}{l}\text { Watershed characteristics } \\
\text { - Percent agricultural (row crops) }\end{array}$ & $\mathrm{X}$ & $\mathrm{X}$ \\
\hline
\end{tabular}



APPENDIX A. DATA VARIABLES AND SOURCES

Table A1. Descriptors of variables (and their sources) used in site classification clustering analysis.

\begin{tabular}{|c|c|c|c|c|c|}
\hline Field alias & Field name & $\begin{array}{r}\text { Description } \\
\end{array}$ & Source & Data scale & Units \\
\hline DB_ID & objectid & Unique database identifier & & & \\
\hline COMID & comid & Unique stream reach identifier & NHDPlusV2 & Reach & NA \\
\hline Stream name & gnis_name & Stream name & NHDPlusV2 & Reach & NA \\
\hline State & state & State in which the reach lies & NHDPlusV2 & State & NA \\
\hline Mean annual flow & qa_ma & Mean annual flow from runoff & ORNL SMH & Reach & $\mathrm{cfs}$ \\
\hline $\begin{array}{l}\text { Generation cluster } \\
\text { number }\end{array}$ & gen10clstr & Generation clusters & NHDPlusV2 & Reach & NA \\
\hline $\begin{array}{l}\text { Generation cluster } \\
\text { description }\end{array}$ & genclusterdef & Short text description of generation clusters & ORNL SMH & Reach & NA \\
\hline $\begin{array}{l}\text { Water quality cluster } \\
\text { number }\end{array}$ & wq10clstrs & Water quality clusters & ORNL SMH & Reach & NA \\
\hline $\begin{array}{l}\text { Water quality cluster } \\
\text { description }\end{array}$ & wqclusterdef & Short text description of water quality clusters & ORNL SMH & Reach & NA \\
\hline $\begin{array}{l}\text { Sediment cluster } \\
\text { number }\end{array}$ & sed10clstr & Sediment clusters & ORNL SMH & Reach & NA \\
\hline $\begin{array}{l}\text { Sediment cluster } \\
\text { description }\end{array}$ & sedclusterdef & Short text description of sediment clusters & ORNL SMH & Reach & NA \\
\hline $\begin{array}{l}\text { Fish passage cluster } \\
\text { number }\end{array}$ & fpsg10clst & Fish passage clusters & ORNL SMH & Reach & NA \\
\hline $\begin{array}{l}\text { Fish passage cluster } \\
\text { description }\end{array}$ & fshclusterdef & Short text description of fish passage clusters & ORNL SMH & Reach & NA \\
\hline $\begin{array}{l}\text { Foundation cluster } \\
\text { number }\end{array}$ & fnd10clstrs & Foundation clusters & ORNL SMH & Reach & NA \\
\hline $\begin{array}{l}\text { Foundation cluster } \\
\text { description }\end{array}$ & fndclusterdef & Short text description of foundation clusters & ORNL SMH & Reach & NA \\
\hline $\begin{array}{l}\text { Recreation cluster } \\
\text { number }\end{array}$ & rec10clstrs & Recreation clusters & ORNL SMH & Reach & NA \\
\hline $\begin{array}{l}\text { Recreation cluster } \\
\text { description }\end{array}$ & recclusterdef & Short text description of recreation clusters & ORNL SMH & Reach & NA \\
\hline
\end{tabular}




\begin{tabular}{|c|c|c|c|c|c|}
\hline Field alias & Field name & Description & Source & Data scale & Units \\
\hline $\begin{array}{l}\text { Distance to nearest } \\
\text { substation }\end{array}$ & dist2sub & $\begin{array}{l}\text { Distance to nearest substation from reach } \\
\text { midpoint }\end{array}$ & ORNL SMH & Reach & $\mathrm{m}$ \\
\hline NPD count & npd_count & Number of NPDs in reach & ORNL NPD & Reach & Count \\
\hline NPD MW & npd_mw & Total potential MW from NPDs in reach & ORNL NPD & Reach & MW \\
\hline NSD count & nsd_count & Number of NSD sites in reach & ORNL NSD & Reach & Count \\
\hline NSD MW & nsd_mw & Total potential MW from NSD sites in reach & ORNL NSD & Reach & MW \\
\hline Support RPS & supportrps & $\begin{array}{l}\text { Percent of residents within county that support } \\
\text { renewable energy portfolio standards }\end{array}$ & $\begin{array}{l}\text { Yale Climate Opinion } \\
\text { Maps }\end{array}$ & County & $\%$ \\
\hline NERC subregion & subregid & NERC subregion ID & EIA & \begin{tabular}{|l|} 
NERC \\
Subregion
\end{tabular} & NA \\
\hline $\begin{array}{l}\text { Subregion future } \\
\text { population }\end{array}$ & popchngsub & $\begin{array}{l}\text { Projected population increase by } 2050 \text { in } \\
\text { NERC subregion }\end{array}$ & ORNL LandCast & \begin{tabular}{|l|l} 
NERC \\
Subregion
\end{tabular} & $\begin{array}{l}\text { Millions of } \\
\text { individuals }\end{array}$ \\
\hline Population density & popdns10cat & $\begin{array}{l}\text { Population density from } 2010 \text { census in } \\
\text { catchment }\end{array}$ & StreamCat & Catchment & \begin{tabular}{|l|l}
$\begin{array}{l}\text { People per } \\
\text { square km }\end{array}$ \\
\end{tabular} \\
\hline Fish group 1 & grp1 & $\begin{array}{l}\text { Number of ocean-run sturgeon species } \\
\text { (Acipenseriformes) within the reach's HUC8 }\end{array}$ & NatureServe & HUC8 & Count \\
\hline Fish group 2 & grp2 & $\begin{array}{l}\text { Number of inland sturgeon/paddlefish species } \\
\text { (Acipenseriformes) within the reach's HUC8 }\end{array}$ & NatureServe & HUC8 & Count \\
\hline Fish group 3 & grp3 & $\begin{array}{l}\text { Number of ocean-run clupeid species within } \\
\text { the reach's HUC8 }\end{array}$ & NatureServe & HUC8 & Count \\
\hline Fish group 4 & grp4 & $\begin{array}{l}\text { Number of ocean-run eel/lamprey species } \\
\text { within the reach's HUC8 }\end{array}$ & NatureServe & HUC8 & Count \\
\hline Fish group 5 & grp5 & $\begin{array}{l}\text { Number of ocean-run salmonid species within } \\
\text { the reach's HUC } 8\end{array}$ & NatureServe & HUC8 & Count \\
\hline Fish group 6 & grp6 & $\begin{array}{l}\text { Number of inland salmonid species within the } \\
\text { reach's HUC8 }\end{array}$ & NatureServe & HUC8 & Count \\
\hline Fish group 7 & grp7 & $\begin{array}{l}\text { Number of other inland migratory species } \\
\text { within the reach's HUC8 }\end{array}$ & NatureServe & HUC8 & Count \\
\hline $\begin{array}{l}\text { Fish passage } \\
\text { mitigation }\end{array}$ & huc2prentfp & $\begin{array}{l}\text { Percent of mitigation sites in the mitigation } \\
\text { database within the HUC2 that had Tier } 1 \text { fish } \\
\text { passage mitigation required }\end{array}$ & $\begin{array}{l}\text { ORNL Environmental } \\
\text { Mitigation }\end{array}$ & HUC2 & $\%$ \\
\hline $\begin{array}{l}303 \mathrm{~d} \text { listed for } \\
\text { temperature }\end{array}$ & d303_temp & $\begin{array}{l}\text { Stream listed as impaired for temperature on } \\
\text { EPA 303d list }\end{array}$ & US EPA & Reach & NA \\
\hline
\end{tabular}




\begin{tabular}{|c|c|c|c|c|c|}
\hline Field alias & Field name & Description & Source & Data scale & Units \\
\hline $\begin{array}{l}303 \mathrm{~d} \text { listed for } \\
\text { sediment }\end{array}$ & d303_sdmnt & $\begin{array}{l}\text { Stream listed as impaired for sediment on } \\
\text { EPA 303d list }\end{array}$ & US EPA & Reach & NA \\
\hline 303d listed for $\mathrm{pH}$ & d303_ph & $\begin{array}{l}\text { Stream listed as impaired for } \mathrm{pH} \text { on EPA 303d } \\
\text { list }\end{array}$ & US EPA & Reach & NA \\
\hline $\begin{array}{l}303 \mathrm{~d} \text { listed for } \\
\text { nutrients }\end{array}$ & d303_ntrnt & $\begin{array}{l}\text { Stream listed as impaired for nutrients on EPA } \\
\text { 303d list }\end{array}$ & US EPA & Reach & NA \\
\hline $\begin{array}{l}303 d \text { listed for } \\
\text { turbidity }\end{array}$ & d303_trbdt & $\begin{array}{l}\text { Stream listed as impaired for turbidity on EPA } \\
\text { 303d list }\end{array}$ & US EPA & Reach & NA \\
\hline $\begin{array}{l}\text { 303d listed for } \\
\text { dissolved oxygen }\end{array}$ & d303_do & $\begin{array}{l}\text { Stream listed as impaired for dissolved } \\
\text { oxygen on EPA 303d list }\end{array}$ & US EPA & Reach & NA \\
\hline $\begin{array}{l}\text { Upstream mainstem } \\
\text { dams }\end{array}$ & umct & Upstream mainstem dam count & MSU Dam metrics DB & Mainstem & Count \\
\hline Upstream dams & unct & Total upstream dam count & MSU Dam metrics DB & Watershed & Count \\
\hline $\begin{array}{l}\text { Downstream } \\
\text { mainstem dams }\end{array}$ & dmct & Downstream mainstem dam count & MSU Dam metrics DB & $\begin{array}{l}\text { Downstream } \\
\text { flowpath }\end{array}$ & Count \\
\hline $\begin{array}{l}\text { Total mainstem dam } \\
\text { count }\end{array}$ & tmct & Total mainstem dam count & MSU Dam metrics DB & Mainstem & Count \\
\hline $\begin{array}{l}\text { Distance to upstream } \\
\text { mainstem dam }\end{array}$ & um $2 d$ & Distance to upstream mainstem dam & MSU Dam metrics DB & Mainstem & Count \\
\hline $\begin{array}{l}\text { Distance to } \\
\text { downstream mainstem } \\
\text { dam }\end{array}$ & $\operatorname{dm} 2 d$ & Distance to downstream mainstem dam & MSU Dam metrics DB & Mainstem & Count \\
\hline $\begin{array}{l}\text { Mainstem dist. } \\
\text { between up/down } \\
\text { dams }\end{array}$ & $\operatorname{tm} 2 d$ & $\begin{array}{l}\text { Total mainstem distance between upstream } \\
\text { and/or downstream mainstem dams }\end{array}$ & MSU Dam metrics DB & Mainstem & Count \\
\hline $\begin{array}{l}\text { Percentage discharge } \\
\text { stored in reservoirs }\end{array}$ & udor & $\begin{array}{l}\text { Percentage of estimated annual discharge } \\
\text { stored in upstream reservoirs }\end{array}$ & MSU Dam metrics DB & Watershed & Count \\
\hline Upstream dam density & damundr & $\begin{array}{l}\text { Upstream network dam density per unit } \\
\text { stream network length }\end{array}$ & MSU Dam metrics DB & Watershed & $(\# / 100 \mathrm{~km})$ \\
\hline $\begin{array}{l}\text { Downstream dam } \\
\text { density }\end{array}$ & damdmd & $\begin{array}{l}\text { Downstream mainstem dam density per unit } \\
\text { downstream mainstem length }\end{array}$ & MSU Dam metrics DB & $\begin{array}{l}\text { Downstream } \\
\text { flowpath }\end{array}$ & $(\# / 100 \mathrm{~km})$ \\
\hline Depth to bedrock & rckdepcat & Mean depth to bedrock in catchment & USGS WRD NSDI & Catchment & $\mathrm{cm}$ \\
\hline Percent clay in soils & pctclayws & Percent clay content of soils in watershed & StreamCat & Watershed & $\%$ \\
\hline Percent sand in soils & petsandws & Percent sand content of soils in watershed & StreamCat & Watershed & $\%$ \\
\hline
\end{tabular}




\begin{tabular}{|c|c|c|c|c|c|}
\hline Field alias & Field name & Description & Source & Data scale & Units \\
\hline Ground acceleration & grndaccel & $\begin{array}{l}\text { Earthquake susceptibility from national } \\
\text { seismic hazard map }\end{array}$ & $\begin{array}{l}\text { USGS seismic hazard } \\
\text { maps }\end{array}$ & Reach & NA \\
\hline K-factor in catchment & kffactcat & $\begin{array}{l}\text { The Kffactor-relative index of susceptibility } \\
\text { of bare, cultivated soil to particle detachment } \\
\text { and transport by rainfall in catchment }\end{array}$ & StreamCat & Catchment & NA \\
\hline K-factor in watershed & kffactws & $\begin{array}{l}\text { The Kffactor-relative index of susceptibility } \\
\text { of bare, cultivated soil to particle detachment } \\
\text { and transport by rainfall in watershed }\end{array}$ & StreamCat & Watershed & NA \\
\hline UCS low & ucsLow & $\begin{array}{l}\text { Unconfined compressive strength of primary } \\
\text { lithology - low end of range }\end{array}$ & $\begin{array}{l}\text { UTK Hydraulics and } \\
\text { Sedimentation Lab }\end{array}$ & Geologic unit & NA \\
\hline UCS high & ucsHigh & $\begin{array}{l}\text { Unconfined compressive strength of primary } \\
\text { lithology_-high end of range }\end{array}$ & $\begin{array}{l}\text { UTK Hydraulics and } \\
\text { Sedimentation Lab }\end{array}$ & Geologic unit & NA \\
\hline Primary lithology & lithlgyprmry & Primary lithology & USGS geologic maps & Geologic unit & NA \\
\hline Rock type & rocktype & Type of underlying bedrock & $\begin{array}{l}\text { UTK Hydraulics and } \\
\text { Sedimentation Lab }\end{array}$ & Geologic unit & NA \\
\hline Stream order & streamorde & Strahler stream order & NHDPlusV2 & Reach & NA \\
\hline Elevation & minelevsmo & Elevation at downstream end of reach & NHDPlusV2 & Reach & $\mathrm{cm}$ \\
\hline Slope & slope & Slope of stream reach & NHDPlusV2 & Reach & $\mathrm{m} / \mathrm{m}$ \\
\hline Stream power & powerQS & SLOPE *QA_MA & ORNL SMH & Reach & NA \\
\hline Mean annual velocity & va_ma & Mean annual velocity for QA & NHDPlusV2 & Reach & fps \\
\hline $\begin{array}{l}\text { Infiltration-excess } \\
\text { overland flow }\end{array}$ & ieofcat & $\begin{array}{l}\text { Mean infiltration-excess overland flow in } \\
\text { catchment }\end{array}$ & USGS WRD NSDI & Catchment & $\begin{array}{l}\begin{array}{l}\% \text { total } \\
\text { stormflow }\end{array} \\
\end{array}$ \\
\hline Runoff in watershed & runoffws & Mean runoff in watershed & StreamCat & Watershed & $\mathrm{mm}$ \\
\hline Flow variation & qa_cv & $\begin{array}{l}\text { Coefficient of variation for flow based on } \\
\text { monthly averages and annual mean }\end{array}$ & NHDPlusV2/ORNL & Reach & NA \\
\hline $\begin{array}{l}\text { Elevation change in } \\
\text { watershed }\end{array}$ & elevdiffws & $\begin{array}{l}\text { Difference between maximum and minimum } \\
\text { elevation in watershed }\end{array}$ & NHDPlusV2/ORNL & Watershed & $\mathrm{cm}$ \\
\hline Base flow index & bficat & $\begin{array}{l}\text { Base flow index is the ratio of base flow to } \\
\text { total flow, expressed as a percentage }\end{array}$ & USGS WRD NSDI & Catchment & $\%$ \\
\hline $\begin{array}{l}\text { Agriculture in } \\
\text { catchment }\end{array}$ & pctagcat & Percent agricultural land cover in catchment & StreamCat & Catchment & $\%$ \\
\hline $\begin{array}{l}\text { Agriculture in } \\
\text { watershed }\end{array}$ & pctagws & Percent agricultural land cover in watershed & StreamCat & Watershed & $\%$ \\
\hline
\end{tabular}




\begin{tabular}{|c|c|c|c|c|c|}
\hline Field alias & Field name & Description & Source & Data scale & Units \\
\hline Nitrogen from farms & farmncat & $\begin{array}{l}\text { Sum total of nitrogen from farm areas in } \\
\text { catchment }\end{array}$ & USGS WRD NSDI & Catchment & $\%$ \\
\hline $\begin{array}{l}\text { Forest/wetlands in } \\
\text { catchment }\end{array}$ & pctforwetcat & $\begin{array}{l}\text { Percent forest and wetland land cover in } \\
\text { watershed }\end{array}$ & NLCD 2011 & Catchment & $\%$ \\
\hline $\begin{array}{l}\text { Forest/wetlands in } \\
\text { watershed }\end{array}$ & pctforwetws & $\begin{array}{l}\text { Percent forest and wetland land cover in } \\
\text { watershed }\end{array}$ & NLCD 2011 & Watershed & $\%$ \\
\hline $\begin{array}{l}\text { Imperviousness in } \\
\text { catchment }\end{array}$ & pctimprv06cat & $\begin{array}{l}\text { Percent imperviousness from } 2006 \text { in } \\
\text { catchment }\end{array}$ & StreamCat & Catchment & $\%$ \\
\hline $\begin{array}{l}\text { Imperviousness in } \\
\text { watershed }\end{array}$ & pctimprv06ws & $\begin{array}{l}\text { Percent imperviousness from } 2006 \text { in } \\
\text { watershed }\end{array}$ & StreamCat & Watershed & $\%$ \\
\hline $\begin{array}{l}\text { Riparian forest in } \\
\text { watershed }\end{array}$ & pctforripws & Percent riparian forest land cover in watershed & StreamCat & Watershed & $\%$ \\
\hline HUC6 & huc6 & 6-digit HUC watershed & USGS WBD & HUC6 & NA \\
\hline $\begin{array}{l}\text { Population density in } \\
\text { HUC6 }\end{array}$ & popdns10huc6 & Mean population density in HUC6 & StreamCat/ORNL & HUC6 & $\begin{array}{l}\text { People per sq } \\
\mathrm{km}\end{array}$ \\
\hline Boat ramps in HUC6 & boat_ramp & Number of developed boat ramps in HUC6 & Delorme/ORNL & HUC6 & Count \\
\hline $\begin{array}{l}\text { Undeveloped boat } \\
\text { ramps in HUC6 }\end{array}$ & boat_ramp_undeveloped & Number of undeveloped boat ramps in HUC6 & Delorme/ORNL & HUC6 & Count \\
\hline Fishing cold water & fishing_coldwater & $\begin{array}{l}\text { Number of cold-water fishing locations in } \\
\text { HUC6 }\end{array}$ & Delorme/ORNL & HUC6 & Count \\
\hline Fishing saltwater & fishing_saltwater & Saltwater fishing locations in HUC6 & Delorme/ORNL & HUC6 & Count \\
\hline $\begin{array}{l}\text { Whitewater paddling } \\
\text { in HUC6 }\end{array}$ & awhuc6km & $\begin{array}{l}\text { Length of stream identified as whitewater } \\
\text { paddling runs in HUC6 }\end{array}$ & $\begin{array}{l}\text { American } \\
\text { Whitewater/ORNL }\end{array}$ & HUC6 & $\mathrm{m}$ \\
\hline $\begin{array}{l}\text { Outstanding rivers in } \\
\text { HUC6 }\end{array}$ & nrirechuc6km & $\begin{array}{l}\text { Length of stream identified as having } \\
\text { outstanding recreational value in HUC6 }\end{array}$ & $\begin{array}{l}\text { National Rivers } \\
\text { Inventory }\end{array}$ & HUC6 & $\mathrm{m}$ \\
\hline Reach length & st_length(shape) & Reach length & NHDPlusV2 & & $\mathrm{m}$ \\
\hline
\end{tabular}


Table A2. Data sources with links.

\begin{tabular}{|l|l|}
\hline \multicolumn{1}{|c|}{ Source } & \multicolumn{1}{c|}{ URL } \\
\hline NHDPlusV2 & http://www.horizon-systems.com/nhdplus/NHDPlusV2_home.php \\
\hline ORNL SMH & $\underline{\text { https://hydropower.ornl.gov/smh/ }}$ \\
\hline ORNL NPD & $\underline{\text { https://nhaap.ornl.gov/content/non-powered-dam-potential }}$ \\
\hline ORNL NSD & $\underline{\text { https://nhaap.ornl.gov/nsd }}$ \\
\hline Yale Climate Opinion Maps & $\underline{\text { http://climatecommunication.yale.edu/visualizations-data/ycom-us-2016/ }}$ \\
\hline EIA & $\underline{\text { https://www.eia.gov/maps/layer info-m.php }}$ \\
\hline ORNL LandCast & $\underline{\text { http://www.pnas.org/content/112/5/1344 }}$ \\
\hline StreamCat & $\underline{\text { https://www.epa.gov/national-aquatic-resource-surveys/streamcat }}$ \\
\hline NatureServe & $\underline{\text { http://www.natureserve.org/conservation-tools/data-maps-tools/digital-distribution-native-us-fishes-watershed }}$ \\
\hline ORNL Environmental Mitigation & $\underline{\text { https://nhaap.ornl.gov/environmental-mitigation }}$ \\
\hline US EPA & $\underline{\text { https://www.epa.gov/waterdata/waters-geospatial-data-downloads }}$ \\
\hline MSU Dam metrics DB & $\underline{\text { https://www.sciencedirect.com/science/article/pii/S004896971730308X?via\%3Dihub }}$ \\
\hline USGS WRD NSDI & $\underline{\text { https://water.usgs.gov/lookup/getgislist }}$ \\
\hline USGS seismic hazard maps & $\underline{\text { https://earthquake.usgs.gov/hazards/hazmaps/ }}$ \\
\hline UTK Hydraulics and Sedimentation & $\underline{\text { http://hsl.engr.utk.edu/ }}$ \\
\hline Lab & $\underline{\text { https://mrdata.usgs.gov/geology/state/ }}$ \\
\hline USGS geologic maps & $\underline{\text { https://www.mrlc.gov/nlcd2011.php }}$ \\
\hline NLCD 2011 & $\underline{\text { https://nhd.usgs.gov/wbd.html }}$ \\
\hline USGS WBD & $\underline{\text { https://developer.garmin.com/datasets/overview }}$ \\
\hline Delorme/ORNL & $\underline{\text { https://www.americanwhitewater.org/ }}$ \\
\hline American Whitewater/ORNL & $\underline{\text { https://www.nps.gov/subjects/rivers/data.htm }}$ \\
\hline National Rivers Inventory &
\end{tabular}

